\title{
New Palladium(II) and Platinum(II) Complexes Based on Pyrrole Schiff Bases: Synthesis, Characterization, X-ray Structure, and Anticancer Activity
}

Simon N. Mbugua, Nicole R. S. Sibuyi, Lydia W. Njenga, Ruth A. Odhiambo, Shem O. Wandiga, Mervin Meyer, Roger A. Lalancette, and Martin O. Onani*

Cite This: ACS Omega 2020, 5, 14942-14954

Read Online

ACCESS | Lلll Metrics \& More | 国 Article Recommendations | s supporting Information

ABSTRACT: New palladium (Pd)II and platinum (Pt)II complexes (C1-C5) from the Schiff base ligands, R-(phenyl)methanamine (L1), R-(pyridin-2-yl)methanamine (L2), and R-(furan2-yl)methanamine (L3) (R-(E)-N-((1H-pyrrol-2-yl) methylene)) are herein reported. The complexes (C1-C5) were characterized by FTIR, ${ }^{1} \mathrm{H}$ and ${ }^{13} \mathrm{C}$ NMR, UV-vis, and microanalyses. Single-crystal X-ray crystallographic analysis was performed for the two ligands (L1-L2) and a Pt complex. Both $\mathbf{L} 1$ and $\mathbf{L 2}$ belong to $P 2_{1} / n$ monoclinic and P-1 triclinic space systems, respectively. The complex C5 belongs to the $P 21 / c$ monoclinic space group. The investigated molar conductivity of the complexes in DMSO gave the range $4.0-8.8 \mu \mathrm{S} / \mathrm{cm}$, suggesting neutrality, with $\log P$ values $\geq 1.2692 \pm 0.004$, suggesting lipophilicity. The anticancer activity and mechanism of the complexes were investigated against various human cancerous (Caco-2, HeLa, HepG2, MCF-7, and PC-3) and noncancerous (MCF-12A) cell lines using 3-(4,5-dimethylthiazol-2-yl)-2,5-diphenyltetrazolium bromide (MTT) and Apopercentage assays, respectively. C5 demonstrated strong DNA-binding affinity for calf thymus DNA (CT-

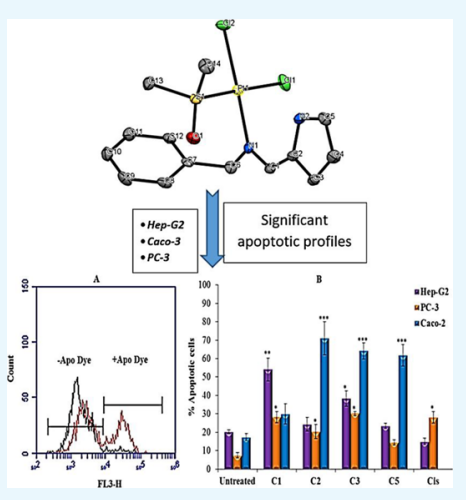
DNA) with a binding constant of $8.049 \times 10^{4} \mathrm{M}^{-1}$. C3 reduced cell viability of all the six cell lines, which included five cancerous cell lines, by more than $80 \%$. The C5 complex also demonstrated remarkably high selectivity with no cytotoxic activity toward the noncancerous breast cell line but reduced the viability of the five cancerous cell lines, which included one breast cancer cell line, by more than $60 \%$. Further studies are required to evaluate the selective toxicity of these two complexes and to fully understand their mechanism of action.

\section{INTRODUCTION}

According to WHO, Cancer is the second leading cause of death globally and is responsible for an estimated 9.6 million deaths in 2018. ${ }^{1}$ Globally, about 1 in 6 deaths is due to cancer. ${ }^{2}$ New anticancer agents, which can effectively treat this disease with minimal side effects, remain of primary importance to the world research community. ${ }^{3-5}$

The development of drug resistance and disease relapse are major challenges in anticancer drug development. ${ }^{6}$ This factor is of crucial significance in the world where this disease continues to burden global health care systems and escalate the mortality rates. ${ }^{7}$ Metals have long been useful in treatment of various ailments known to man. Because of their unique properties, metal complexes, especially those containing transition metals have gained tremendous attention as anticancer agents. ${ }^{9}$ Most recently, the metal complexes derived from pyrrole moieties have shown good antiproliferative activity against lymphocytic, cervical, and breast cancer cells. ${ }^{10-12}$ A series of pyrrole-based ferrocene complexes were also reported to be cytotoxic against breast cancer (MCF-7), ${ }^{13}$ colon cancer (HT-29) cell lines, and noncancerous breast cells (MCF-10A). ${ }^{14}$ Equally, the known cancer drug to date, cisplatin has undergone various derivatization. The analogues containing bulky groups have displayed enhanced cytotoxicity profiles against cisplatinresistant cells. This led to a conclusion that the steric shielding of the metal center can regulate ligand substitution and consequently increase an efficiency to DNA binding. ${ }^{15}$ The binding interactions is best followed by spectroscopy studies, where an observation of the alterations in the $\lambda_{\max }$ absorption values appear as a result of $\pi-\pi^{*}$ intraligand transitions, ligand $\rightarrow$ metal/metal $\rightarrow$ ligand charge transfers, or on the $d-d$ transitions. ${ }^{16}$ During any of these mentioned processes, the DNA concentration is serially increased to the metal complex. Various modes of binding are then deduced from the spectral response, whereby an intercalative manner of interaction is specified by a hypochromic shift, bathochromic shift, or hypsochromism. ${ }^{17}$ Intercalation of a complex with the base

Received: January 25, 2020

Accepted: May 14, 2020

Published: June 19, 2020 
Scheme 1. Synthetic Routes for the Ligands and Their Corresponding Complexes; (i) Pd(cod)ClMe, DCM, Room Temperature, $12 \mathrm{~h}$; (ii) $\mathrm{Pt}(\mathrm{DMSO})_{2} \mathrm{Cl}_{2}, \mathrm{DCM}$, Room Temperature; (iii) and (iv) Pd(cod)Cl $\mathrm{Cl}_{2}$ DCM, Room Temperature, 12 h; (v) Crystals Grown by Slow Evaporation of a DCM Solution of C4

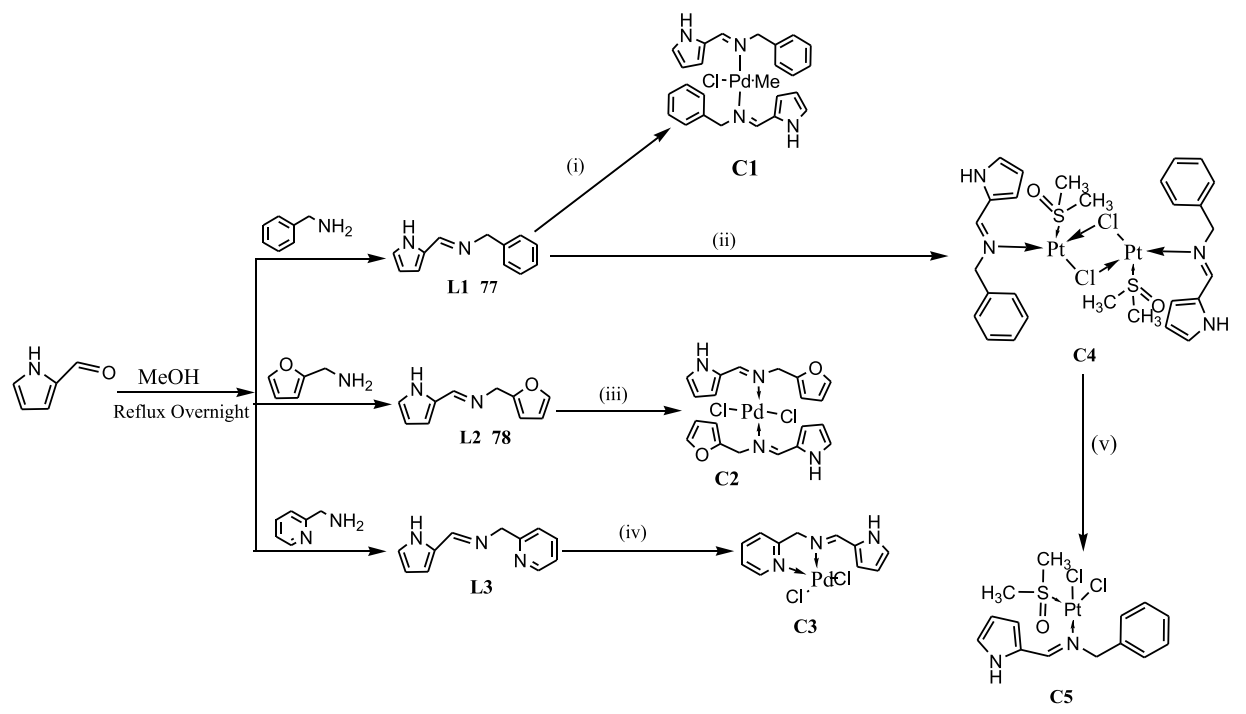

pairs of DNAs is as a result of overlaps of $\pi^{*}$-antibonding orbitals of the ligands bound to the complex with $\pi$-bonding orbitals of the DNA base pairs. ${ }^{18}$ This decreases the probable transitions, and the effect is observed as a hypochromic shift. ${ }^{19}$ On the other hand, a hyperchromic shift suggests electrostatic mode of binding. The spectral shift in the metal complex absorption is correlated to the binding strength from which the kinetics can then be determined. ${ }^{20}$ The investigation of drugDNA interaction is important in understanding the molecular mechanism of drug action and for the design of the specific DNA-targeted drug.

Although the Schiff base ligands are reported in literature for $\mathrm{C}-\mathrm{C}$ coupling reactions, ${ }^{21}$ their use in $\mathrm{Pt}$ or Pd complexes in anticancer studies has been limitedly studied, particularly, the pyrrole based Schiff bases. In this regard, the ligands and their corresponding $\mathrm{Pd}(\mathrm{II})$ and $\mathrm{Pt}(\mathrm{II})$ complexes were synthesized and characterized followed by investigation of their DNA binding and anticancer activities. The motivation behind this study was two-fold. First, these complexes have square planar geometry analogous to the common anticancer drug, cisplatin, but bears sterically bulky substituents around the metal center. This is a strategy reported in literature for prevention of an axial approach to the metal atom from the $z^{2}$ direction, thus hindering the formation of a trigonal bipyramid intermediate, which leads to ligand substitution. ${ }^{22}$ In this way, the sterically bulky groups shield the labile ligands, therefore reducing the rate of hydrolysis and substitution long enough for the complexes to bind to the desired target. Second, the transgeometry complexes have not been widely explored as anticancer agents despite literature reports that they could exhibit cytotoxicity equivalent to or greater than that of cisplatin. $^{23-25}$

\section{RESULTS AND DISCUSSION}

Synthesis of Organometallic Complexes. A series of pyrrole-based ligands and their corresponding $\mathrm{Pd}(\mathrm{II})$ and $\mathrm{Pt}$ (II) complexes are synthesized, as shown in Scheme 1. The ligands (L1-L3) were synthesized by standard Schiff base condensation reaction of pyrrole-2-carboxaldehyde either with benzyl amine (L1), 2-furanmethyl amine (L2), or 2-picoly- amine (L3), under reflux overnight. To the best of our knowledge, this is the first time that the crystal structures of $\mathbf{L} 1$ and $\mathbf{L} \mathbf{2}$ are reported. The metal complexes $(\mathbf{C 1}-\mathbf{C 5})$ were obtained through the reaction of $\mathrm{Pd}(\operatorname{cod}) \mathrm{Cl}_{2}, \mathrm{Pd}(\operatorname{cod}) \mathrm{ClMe}$, or $\mathrm{Pt}(\mathrm{DMSO})_{2} \mathrm{Cl}_{2}$ precursors with a solution of ligand in $\mathrm{DCM}$ at room temperature. The complexes $(\mathrm{C} 1$ and $\mathrm{C2})$ were formed through a reaction of 1:2 (metal/ligand) molar ratios using ligands $\mathbf{L} 1$ and $\mathbf{L} 2$, while $\mathbf{C} 3$ and $\mathbf{C} 4$ were formed from a 1:1 $\mathrm{M}$ ratio using L3 and L1, respectively, as shown in Error! Reference source not found.. Because of steric factors, the Pd complexes binding at 1:2 ratio (metal/ligand) are believed to be of trans-geometry. Similar work was reported on the bisferrocenyl Schiff base complexed with Pd which confirmed a monodentate binding of the Schiff bases to the metal center through the imine- $\mathrm{N}$ without involving the heteroatoms on the rings. ${ }^{26}$ This resulted in a square planar geometry at the $\mathrm{Pd}$ center. These ratios were confirmed by elemental analysis.

The elemental analysis showed close agreement with the theoretical calculations confirming the proposed structures of the compounds. An interesting observation was made for the Pt complex which was shown to exist either as a monomer or a chlorobridged dimer. A chlorobridged dimer (C4) was confirmed by elemental analysis but the structure obtained after growing single crystals corresponded to a monomer (C5). This suggests that the existence of the compound in the amorphous form differed from the crystalline state, whereby the crystal lattice constraints affect a major conformational rearrangement of the individual molecules favoring the free monomer. $^{27}$

Characterization of the Complexes. Fourier Transform Infrared Spectra. The Fourier transform infrared (FTIR) analysis for the compounds was performed using potassium bromide $(\mathrm{KBr})$ pellets. Comparisons were drawn between the transmission frequencies for the azomethine functional groups and those of free ligands. The IR spectrum for the ligands showed clear imine $\mathrm{C}=\mathrm{N}$ (stretch) vibration band which occurred between 1636 and $1644 \mathrm{~cm}^{-1}$. Similar azomethine bands for the complexes occurred between 1592 and 1628 $\mathrm{cm}^{-1}$. The shift was an indication of chelation of $\mathrm{Pd}$ or $\mathrm{Pt}$ through the imine nitrogen, and the magnitude could be 


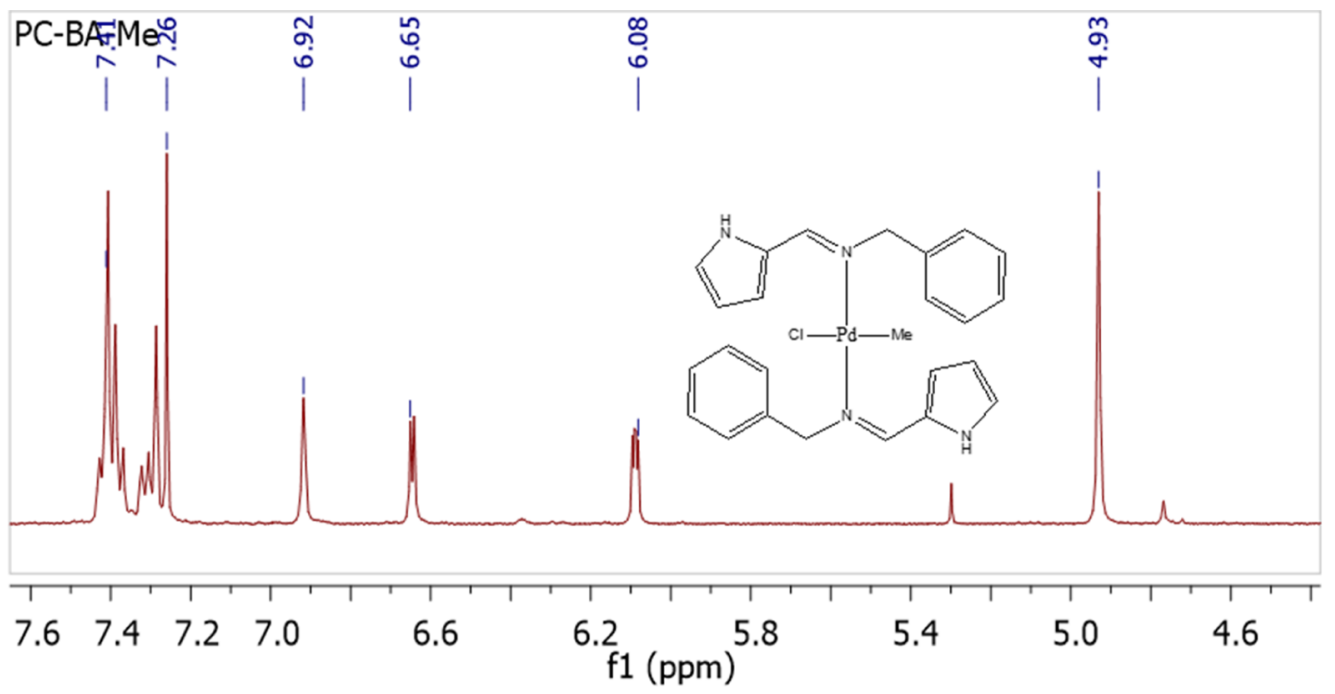

(i)

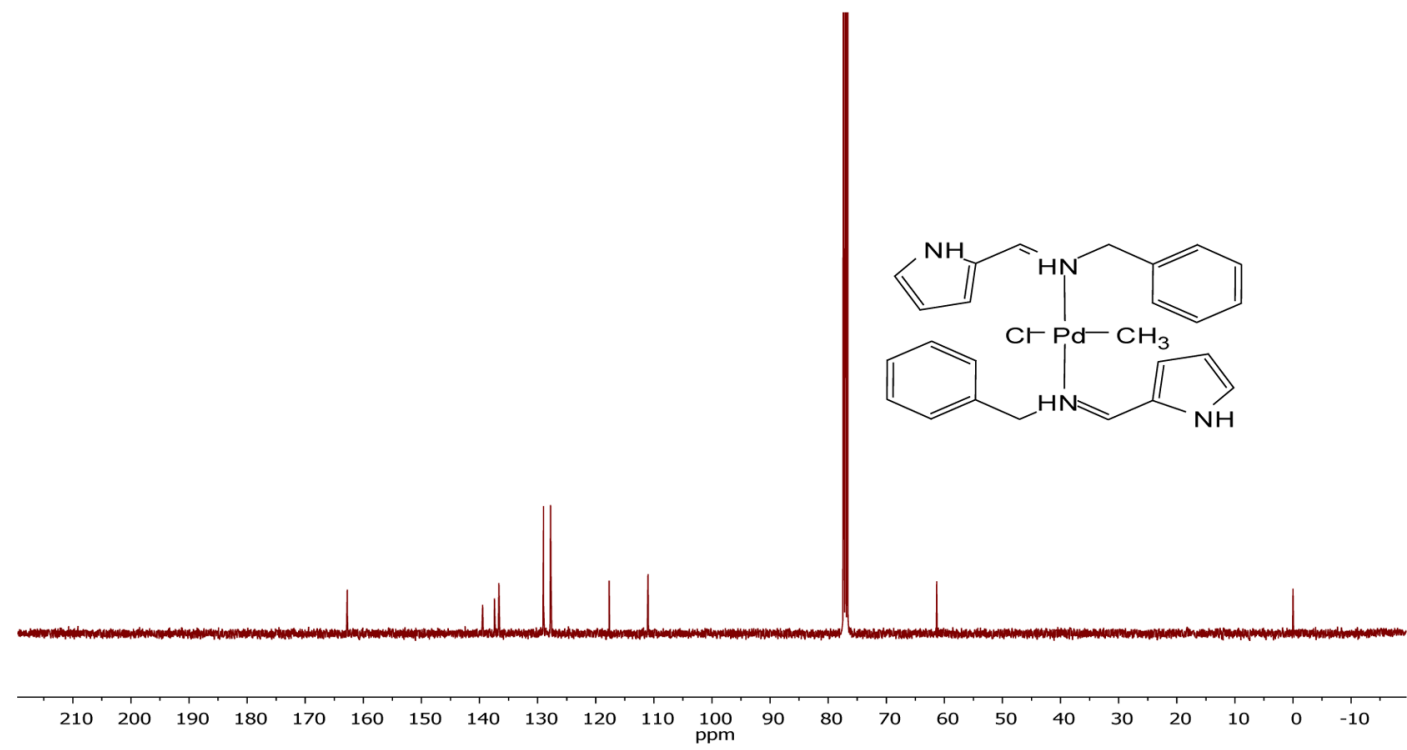

(ii)

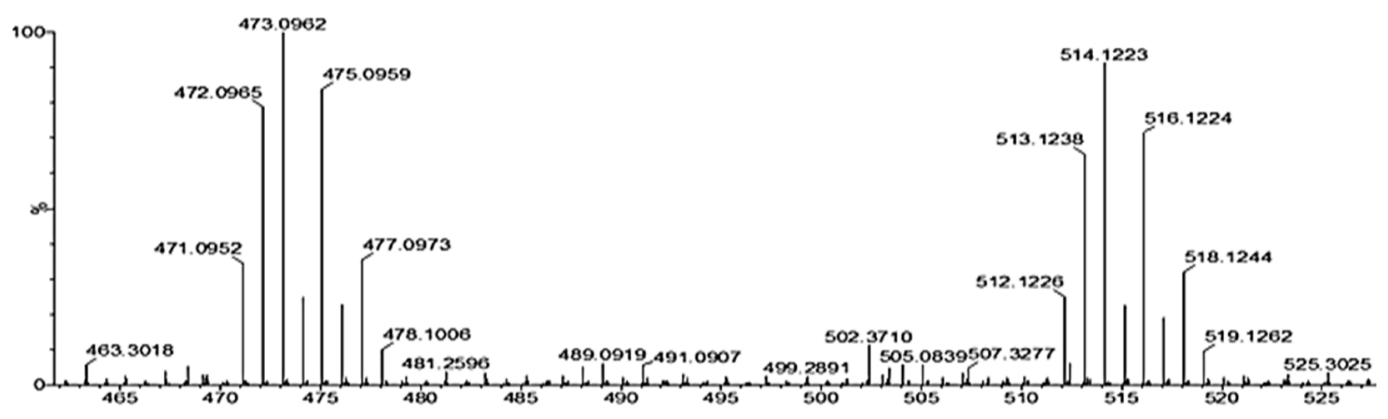

(iii)

Figure 1. Representative spectra; (i) ${ }^{1} \mathrm{H}$ NMR for C1, (ii), ${ }^{13} \mathrm{C}-\mathrm{NMR}$ for C1, and (iii) LC-MS for Complex C1.

attributed to the different ligands attached to the metal center and to the groups attached to the azomethine region. In general, the shifting to lower frequencies is ascribed to the pi- back donation from metal $d$-orbitals to empty pi-antibonding orbitals of $\mathrm{CH}=\mathrm{N}^{28}$ A characteristic peak at $696 \mathrm{~cm}^{-1}$ for platinum complexes and at $598 \mathrm{~cm}^{-1}$ for $\mathrm{Pd}$ complexes 
appeared and was ascribed to the $\nu[\mathrm{M}-\mathrm{N}]$ coordination. The FTIR spectra are shown in Figures $\mathrm{S} 1-\mathrm{S} 7$ in the Supporting Information.

${ }^{1} \mathrm{H}$-NMR Spectra. The ${ }^{1} \mathrm{H}$ NMR spectra for the complexes also showed a similar trend in the shifts in frequency of the methylene protons compared to the free ligands. The peak because of $\mathrm{CH}=\mathrm{N}-$ in $\mathrm{Cl}$ and $\mathrm{C} 4$ occurred at 7.41 and 7.81 ppm, respectively, compared to $8.15 \mathrm{ppm}$ in the parent ligand L1. In complex C2, the peak occurred at $7.69 \mathrm{ppm}$ compared to $8.12 \mathrm{ppm}$ in the parent ligand, L2. In complex $\mathbf{C} 3$, the methylene peak appeared at $7.69 \mathrm{ppm}$ compared to $8.57 \mathrm{ppm}$ in the parent ligand L3. This up-field shifts of $0.74,0.34$, and 1.04 ppm in C1, C3, and C4, respectively, to lower frequencies is because of pi-electrons of the azomethine group shifting toward the $d$-orbitals of metal leading to deshielding of the azomethine proton ${ }^{29,30}$ as a result of coordination to the azomethine nitrogen. The ${ }^{1} \mathrm{H}-\mathrm{NMR}$ spectra are shown in Figures S8-S13 in the Supporting Information.

${ }^{13}$ C-NMR Spectra. Similar trends in shifts to higher frequencies were observed in the ${ }^{13} \mathrm{C}$-NMR peaks for the compounds. The ${ }^{13} \mathrm{C}-\mathrm{NMR}$ spectra are shown in Figures S14S18 in the Supporting Information.

Electronic Spectra. The UV-vis spectra of the ligands and the Pd complexes in dimethyl sulfoxide (DMSO) were measured at the $200-800 \mathrm{~nm}$ range. The molar absorptivity for all the compounds was determined using UV titrations. Ligand spectra showed peaks corresponding to intraligand, spin-allowed pi $\rightarrow \pi^{*}$ centered on the aromatic units in addition to $\mathrm{n} \rightarrow \pi^{*}$. These transitions had molar extinction coefficients ranging from 103 to $104 \mathrm{~L} \mathrm{~mol}^{-1} \mathrm{~cm}^{-1}$. On the other hand, the UV-vis spectra for all the complexes showed two peaks corresponding to a combination of the spin allowed ${ }^{1} \mathrm{~A}_{1 \mathrm{~g}} \rightarrow{ }^{1} \mathrm{~B}_{1 \mathrm{~g}}$ transitions and $d \pi-\pi^{*}$ ligand transitions with molar extinction coefficients ranging from $10^{3}$ to $10^{4} \mathrm{~L} \mathrm{~mol}^{-1}$ $\mathrm{cm}^{-1}$. This transition is characteristic of square planar geometry. The UV-vis spectra are shown in Figures S26S32 in the Supporting Information. Representative spectra for complex $\mathbf{C 1}$ are shown in Figure 1.

Molar Conductance. The molar conductance was measured for the complexes in DMSO and showed values ranging from 4.0 to $8.2 \mathrm{~S} \mathrm{~cm}^{2} \mathrm{~mol} \mathrm{~L}^{-1}$. This is in agreement with other reports in the literature, which indicates a less than $30 \mathrm{~S} \mathrm{~cm}^{2}$ mol $\mathrm{L}^{-1}$ as an indication of nonconductance. This confirms that these types of complexes are nonelectrolytic in solution. ${ }^{31}$

Partition Coefficient. The partition coefficient was determined as $\log P$ values by the UV-vis method. The values were $1.3953 \pm 0.0065$ for C1, $1.3816 \pm 0.0032$ for C2, $1.2692 \pm 0.004$ for C3, and $1.3072 \pm 0.0082$ for C5, indicating a more than 20-times partitioning of the compounds in the oil layer compared to the water layer. This implies that the compounds can be suitable for oral administration. ${ }^{32}$

Electrochemical Properties of the Pd and Pt Complexes. Electrochemical studies were performed on C2, C3, and C5. The cyclic voltammograms are shown in Figure 2 below.

Complex C2 exhibits two irreversible reduction peaks at $-0.57 \mathrm{~V}$ and at $-1.7 \mathrm{~V}$, while $\mathbf{C} 3$ showed reduction peaks with no anodic peaks present at $-0.57 \mathrm{~V}$ and at $-1.47 \mathrm{~V}$ (Figure 2). The observed processes most likely correspond to a metalcentered one-electron reduction process for the two peaks as shown in eqs 1 and 2 .

$$
\operatorname{Pd}(\mathrm{II})+\mathrm{e} \rightarrow \operatorname{Pd}(1) \quad-0.57 \mathrm{~V}
$$

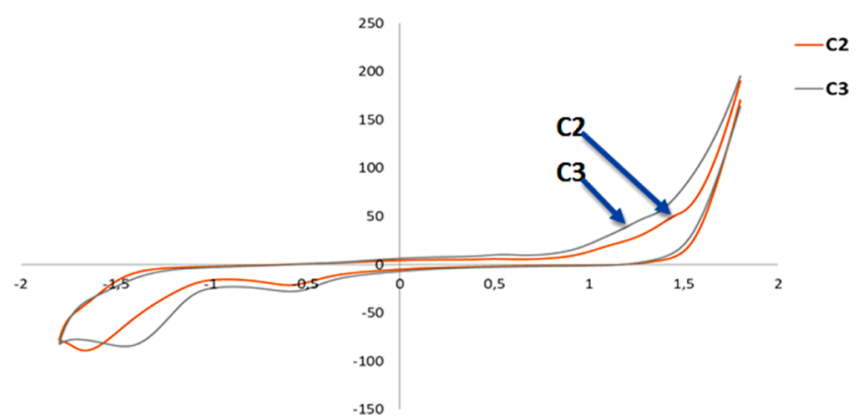

Figure 2. Cyclic voltammograms for $\mathbf{C 2}$ and $\mathbf{C} 3$ showing irreversible reduction peaks.

$$
\begin{aligned}
& \operatorname{Pd}(\mathrm{I})+\mathrm{e} \rightarrow \operatorname{Pd}(0) \\
& \quad-1.47 \mathrm{~V} \text { and }-1.7 \mathrm{~V}(\mathbf{C} 2 \text { and } \mathbf{C} 3 \text { respectively })
\end{aligned}
$$

The cyclic voltammetry for the Pt complexes was performed at a scan rate of $200 \mathrm{mV} / \mathrm{s}$ at $\mathrm{pH} 7.0$ versus $\mathrm{Ag} / \mathrm{AgCl}$, glassy carbon working electrode, and $\mathrm{Pt}$ wire counter electrode. As shown in Figure 3, one peak was observed at $-0.5 \mathrm{~V}$ which was credited to the diffusion-controlled $\mathrm{H}^{+}$reduction to $\mathrm{H}_{2}$ which occurs around $-0.41 \mathrm{~V}$ at $\mathrm{pH} 7$ versus $\mathrm{Ag} / \mathrm{AgCl}{ }^{33}$

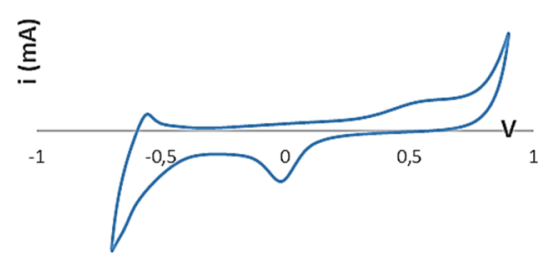

Figure 3. Cyclic voltammograms for C5 showing diffusion-controlled H-reduction.

In physiological systems, the redox stability appears within an accessible window of potential ranging between -0.4 and $+0.8 \mathrm{~V}$ versus normal hydrogen electrode (NHE). ${ }^{34}$ These values correspond to the potentials for the main reducing agents in biological systems; NADPH with approximately $-0.38 \mathrm{~V}$ and oxygen at around $+0.815 \mathrm{~V}$, at $\mathrm{pH} 7.0$ versus NHE. ${ }^{23}$ Typically, all redox processes with a bigger or lesser value of potential compared to this physiological range cannot happen in the biological setting. However, there are other routes by which metal complexes interfere with cellular redox reactions through interaction via their redox centers either on the metal or ligand or through coordinating to biomolecules which facilitate cellular redox mechanisms. ${ }^{35}$

Stability Studies. Stability tests were performed for C1 and C5 in DMSO- $d_{6}$ over a $72 \mathrm{~h}$ period in the presence of 200 $\mu \mathrm{L} \mathrm{D}_{2} \mathrm{O}$. ${ }^{1} \mathrm{HNMR}$ scans were conducted at $6 \mathrm{~h}$ intervals to monitor any changes in proton environments. There were no shifts in peaks or any other change in spectra over the $72 \mathrm{~h}$ period. This indicated that the compounds were stable in solution as shown in the ${ }^{1} \mathrm{H}-\mathrm{NMR}$ plots and could be biocompatible. ${ }^{26}$ The spectra are shown in Figure S33a-c in the Supporting Information.

X-ray Crystal Structure Analysis for Ligands L1 and L2 and C5 Complex. Crystals suitable for X-ray crystallography were grown for $\mathbf{L} 1$ and $\mathbf{L} 2$ and for the C5 Pt complex. The compounds crystallize in the monoclinic $P 2_{1} / n$ space system for L1, P-1 for L3, and $P 2_{1} / c$ for C5. 
The crystal data for the four compounds are shown in Table 1.

Table 1. Single-Crystal Data and Structure Refinement Parameters for L1, L2, and C5

\begin{tabular}{llll}
\multicolumn{1}{c}{ compound } & \multicolumn{1}{c}{ L1 } & \multicolumn{1}{c}{ L2 } & \multicolumn{1}{c}{ C5 } \\
formula & $\mathrm{C}_{12} \mathrm{H}_{12} \mathrm{~N}_{2}$ & $\mathrm{C}_{10} \mathrm{H}_{10} \mathrm{~N}_{2} \mathrm{O}$ & $\mathrm{C}_{14} \mathrm{H}_{18} \mathrm{Cl}_{2} \mathrm{~N}_{2} \mathrm{OPtS}$ \\
space group & $P 2_{1} / n$ & $\mathrm{P}-1$ & $P 2_{1} / c$ \\
cell lengths & $a=9.8330(3)$ & $a=4.8147(1)$ & $a=8.0734(1)$ \\
& $b=17.3251(7)$ & $b=9.1561(3)$ & $b=18.0661(3)$ \\
& $c=11.7851(4)$ & $c=10.0726(3)$ & $c=11.5367(2)$ \\
cell angles & $\alpha 90$ & $\alpha 96.269(1)$ & $\alpha=90$ \\
& $\beta 94.219(2)$ & $\beta 97.570(2)$ & $\beta=94.229(1)$ \\
& $\gamma 90$ & $\gamma 94.171(1)$ & $\gamma=90$ \\
cell volume & 2002.24 & $435.82(2)$ & $1678.10(5)$ \\
$Z$ & 8 & 2 & 4 \\
temperature & $100 \mathrm{~K}$ & $100 \mathrm{~K}$ & $100 \mathrm{~K}$
\end{tabular}

The structure and ORTEP ellipsoid diagram for L1 is shown in Figure 4. The ligand exists as a molecular pair. Stabilization

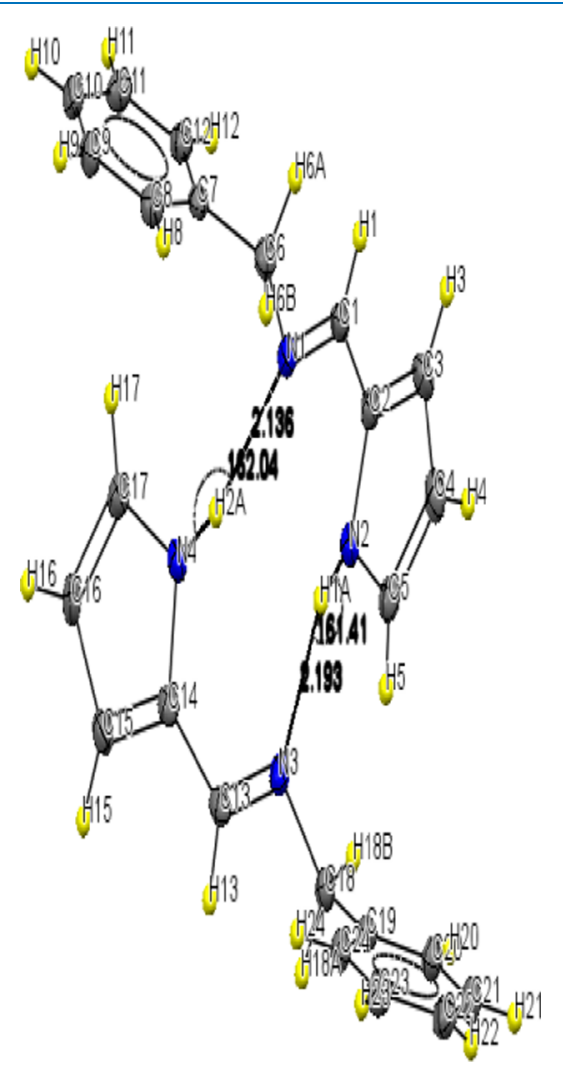

Figure 4. ORTEP Ellipsoids for L1 at 50\% probability showing the intramolecular stabilization through $\mathrm{H}$-bonding.

within the molecule is through intermolecular hydrogen bonding, between the imine nitrogen of one molecule and the hydrogen attached to the pyrrole nitrogen of the second molecule. The intermolecular bond distances are 2.136 and $2.193 \AA$. The intermolecular bond angles subtended by the $\mathrm{H}$ bonded hydrogen are $161.41^{\circ}$ for $\mathrm{N} 2-\mathrm{H} 1-\mathrm{N} 3$ and $162.04^{\circ}$ for $\mathrm{N} 1-\mathrm{H} 2-\mathrm{N} 4$. The pyrrole and the benzyl rings lie at a torsion angle of $123.57^{\circ}$ for one molecule and $118.97^{\circ}$ for the second molecule.

The ORTEP plot for L2 is shown in Figure 5a,b. The crystal is stabilized by intermolecular hydrogen bonding of the

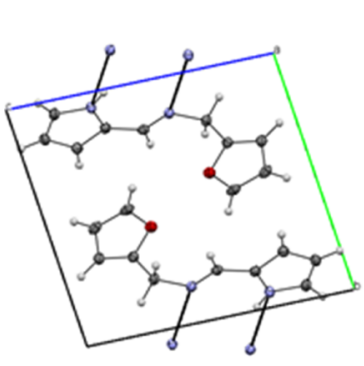

(a)

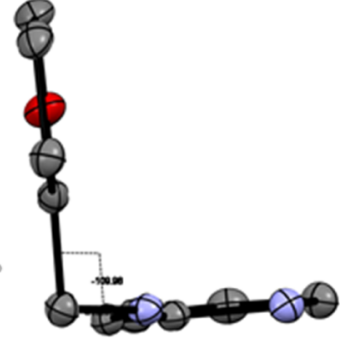

(b)
Figure 5. Unit cell for $\mathrm{L} 2$ viewed along the crystallographic $a$-axis showing hydrogen bonding in the unit cell (a) and the near perpendicular $\left(109.98^{\circ}\right)$ molecular planes (b).

hydrogens attached to imine and pyrrole nitrogen of adjacent molecules but facing away from the center of the molecule to the adjacent crystal units in opposite directions. The pyrrole and furan moieties making up one molecule exist at an almost perpendicular planes to each other, at an angle of $109.98^{\circ}$.

The ORTEP plot for the Pt complex (C5) is shown in Figure $6 \mathrm{a}, \mathrm{b}$ with the unit cell consisting of four molecules. The

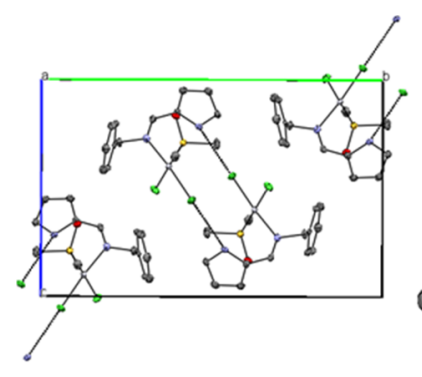

(a)

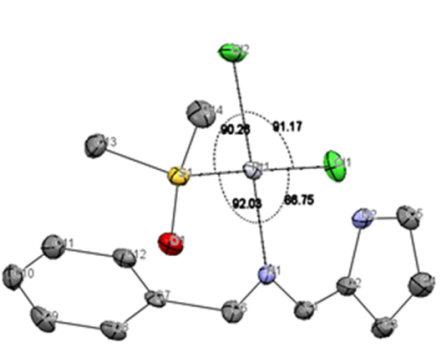

(b)
Figure 6. Unit cell packing showing hydrogen bonding, (a), and bond angles around the Pt center (b) for C5. Hydrogen atoms are omitted for clarity.

angles subtended around the Pt center are approximately right angles confirming the square planar geometry of a $\mathrm{Pt}(\mathrm{II})$ metal oxidation state.

The crystal is stabilized through intermolecular hydrogen bonding ( $3.198 \AA$ A ) between the pyrrole hydrogen and chloride atom para to the imine nitrogen of adjacent molecules. A notable property of this complex is the unequal bond distances between the $\mathrm{Pt}$ metal center and the two chloride atoms attached to it. The bond length between the Pt and chloride para to the imine nitrogen is $2.302 \AA$, while the distance between the $\mathrm{Pt}$ center and chloride atom para to the sulfur atom of DMSO is $2.317 \AA$. This is credited to the stronger ground state trans-influence of sulfur compared to nitrogen, leading to a lengthening (and weakening) of interatomic bonds.

These observations are similar to what was reported by Murray and Hartley on $\mathrm{N}$ - and S-bonded $\mathrm{PdCl}_{2}$ on amino acid backbones. In their work, a bond length of $2.305 \AA$ for $\mathrm{Pd}-\mathrm{Cl}$ trans-to $\mathrm{N}$-atom and $2.324 \AA$ for $\mathrm{Pd}-\mathrm{Cl}$ trans to $\mathrm{S}$ was observed. ${ }^{36}$ It is observed that coordination occurs preferentially between $\mathrm{Pt}$ and sulfur of DMSO rather than with the oxygen atom despite the latter being less sterically hindered. This is expected because $\mathrm{Pt}$, being a soft acid, prefers to coordinate with soft donors such as sulfur as opposed to nitrogen. 
Bioactivity of the Organometallic Complexes. DNA Binding Studies. Observation on the spectral changes of metal complexes in the UV-vis range after addition of increasing concentrations of DNA is a generally accepted technique to assess the mode of binding and the kinetics of DNA-metal complex interaction. ${ }^{37}$ In this study, calf thymus DNA (CTDNA) was used to simulate how the complexes bind to DNA. The metal complex-DNA mixture was allowed to equilibrate for $10 \mathrm{~min}$ prior to taking UV-vis measurements. With continued addition of DNA, the peaks of the complexes decreased up to a point where they disappeared, and a peak at $260 \mathrm{~nm}$ corresponding to DNA appeared. The appearance of the DNA peak at $\lambda 260 \mathrm{~nm}$ was used as an indication of the interaction with the complexes. DNA concentration was calculated using the molar absorptivity of the CT-DNA, $\varepsilon=$ $6600 \mathrm{M}^{-1}$, as shown in Figure S34 in the Supporting Information.

The binding kinetics for the complex-NA interaction was then determined from the intrinsic binding constant, $K_{\mathrm{b}}$, by plots of the Benesi-Hildebrand host-guest equation, ${ }^{38}$ (eq 3), where the strength of the interaction is reflected by the value of the binding constant.

$$
\frac{A_{\mathrm{o}}}{A-A_{\mathrm{o}}}=\frac{\varepsilon_{\mathrm{G}}}{\varepsilon_{\mathrm{H}-\mathrm{G}}-\varepsilon_{\mathrm{G}}}+\frac{\varepsilon_{\mathrm{G}}}{\varepsilon_{\mathrm{H}-\mathrm{G}}-\varepsilon_{\mathrm{G}}} \frac{1}{K_{\mathrm{b}}[\mathrm{DNA}]}
$$

$A_{\mathrm{o}}$ and $A$ are the absorbance of the blank sample without DNA, and absorbance of complex-DNA after addition of DNA, respectively, $\varepsilon_{\mathrm{G}}$ and $\varepsilon_{\mathrm{H}-\mathrm{G}}$ are the molar extinction coefficients of complex only and complex-DNA, respectively. The binding constant is determined by plotting $A_{\mathrm{o}} /\left(A-A_{\mathrm{o}}\right)$ versus $1 /[\mathrm{DNA}]$ to give a straight-line graph. The equation of the straight line gives the slope and intercept, where the $K_{\mathrm{b}}$ value was calculated from the ratio of the intercept to the slope. From the $K_{\mathrm{b}}$ values, Gibbs free energy changes, $\Delta G$, for the complex-DNA interactions were calculated using eq 4 .

$$
\Delta G=-R T \ln K_{\mathrm{b}} \mathrm{kJ} \mathrm{mol}^{-1}
$$

where $R$ is the gas constant and $T$ is the absolute temperature.

The absorption spectra of the interaction of CT-DNA with the complexes together with the Benesi-Hildebrand plots are shown in Figures 7-10. The arrows show the intensity changes upon increasing concentration of CT DNA. Inset is the Benesi-Hildebrand plots for the determination of the binding constant.

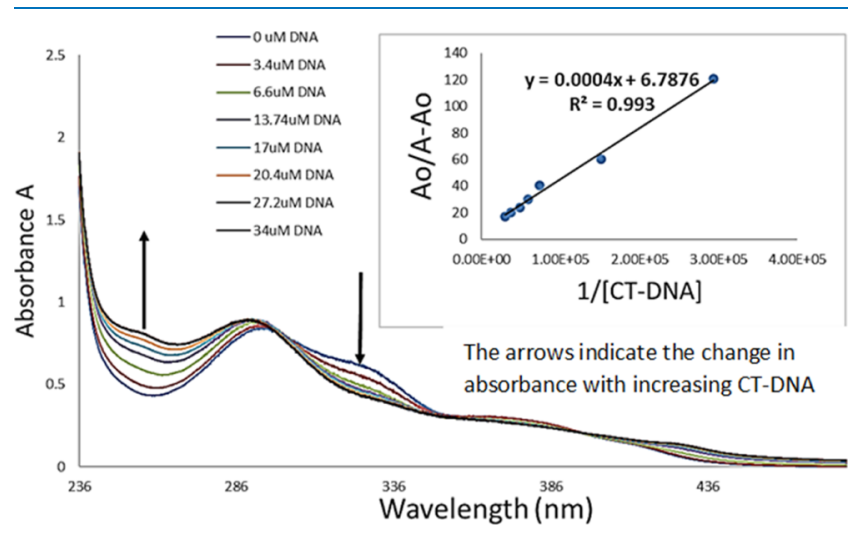

Figure 7. UV-vis absorption spectra for the CT-DNA Interactions with $\mathbf{C 1}$.
The spectra for $\mathbf{C 1}$ (Figure 6) showed a 5\% hyperchromism at $294 \mathrm{~nm}$. The observed hyperchromism is attributed to external associations by electrostatic interactions of the complex with the groove bases in the DNA possibly through the planar aromatic phenyl and pyrrole moieties and from hydrogen bonding with the negatively charged phosphate backbone. $^{39}$ This is further supported by the hypsochromic shift of $6 \mathrm{~nm}$ because a decrease in electron density in piorbitals stabilizes the orbitals, which causes an increase in the energy gap between pi and pi* orbitals, shifting the absorption to a lower wavelength.

On the other hand, the spectra for C2 (Figure 7), C3 (Figure 8), and C5 (Figure 9) showed hypochromic shifts with no shift in wavelength. The hypochromism is explained by the probability of intercalative interactions of the chromophores in the complexes with the DNA base pairs. ${ }^{40}$ Furthermore, distinct isosbestic points appeared at $300 \mathrm{~nm}$ in the spectrum of $\mathbf{C 1}$ and $285 \mathrm{~nm}$ in the spectra of C2, C3, and C5. This is a clear indication of equilibrium between bound DNA and the free form of the compounds and that no other species apart from the free and the intercalated forms were present in the mixture. ${ }^{41}$ The mode of binding, $K_{\mathrm{b}}$ values, and Gibbs free energy for the complexes are shown in Table 2.

These values indicate a comparatively strong interaction between the complexes and CT-DNA. Complexes C1, C2, and C3 had lower binding constants which are comparable to the values of the known DNA intercalators: Lumazine, Epirubicin, and Proflavine $\left(2.32 \times 10^{4} \mathrm{M}^{-1}\right){ }^{42}$ The Pt complex C5 showed higher $K_{\mathrm{b}}$ values than those of Lumazine, Epirubicin $\left(3.4 \times 10^{4} \mathrm{M}^{-1}\right),{ }^{42}$ and Proflavine $\left(1.74 \times 10^{4} \mathrm{M}^{-1}\right)^{43}$ but lower than that of ethidium bromide $\left(1.4 \times 10^{6} \mathrm{M}^{-1}\right){ }^{44}$ This strong affinity to bind to the DNA indicates its significance as a possible candidate in the line of potential anticancer drug candidates. The high binding constant for C5 suggests that it can also be a viable candidate for new intercalator compounds. The $\Delta G$ values for all the complexes were negative which specified the spontaneity of interaction during the complexDNA formation process. ${ }^{42}$

Anticancer Activity of the Organometallic Complexes. The main objective of the study was to demonstrate that stabilizing $\mathrm{Pt}$ and $\mathrm{Pd}$ by complexing with sterically bulky substituents around the metal center can block the attack from the axial $\mathrm{z}^{2}$-direction of the square planar complexes, thereby reducing ligand substitution reactions when in solution ${ }^{8}$ and improving their activities. Cytotoxicity of the compounds was assessed by MTT assay on selected cancerous (Caco-2, HeLa, Hep-G2, MCF-7, and PC-3), and noncancerous (MCF-12A) cell lines. The cells were initially treated with a single dose $(100 \mu \mathrm{g} / \mathrm{mL})$ of the ligands $(\mathbf{L} 1-3)$ and their respective complexes $(\mathbf{C 1 - 5})$ to evaluate their potential anticancer activity. The ligands did not show any substantial activity at this dose (data not shown) compared to their corresponding complexes, and therefore, the reduced cell proliferation shown in Figure 11 could be accredited to the complexed compounds.

Two complexes (C3 and C5) were highly toxic to the cancer cells. C3 reduced cell viability by more than $80 \%$ in the six cell lines evaluated in this study and was the most cytotoxic complex. C5 demonstrated remarkable selective toxicity. It reduced viability of all the cancer cell lines by $60 \%$ or more but did not affect the viability of the noncancerous KMST6MCF$12 \mathrm{~A}$ cells. In general, $\mathbf{C} 1$ and $\mathbf{C} 2$ was less toxic but also demonstrated some level of selective toxicity. C2, for example, did not significantly reduce the viability of Caco-2 and MCF-7 


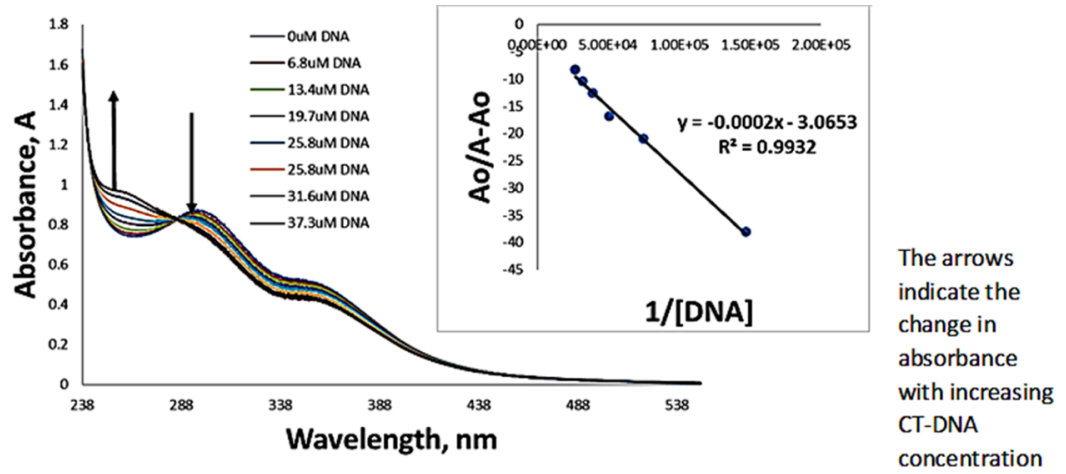

Figure 8. UV-vis absorption spectra for the CT-DNA interactions with C2.

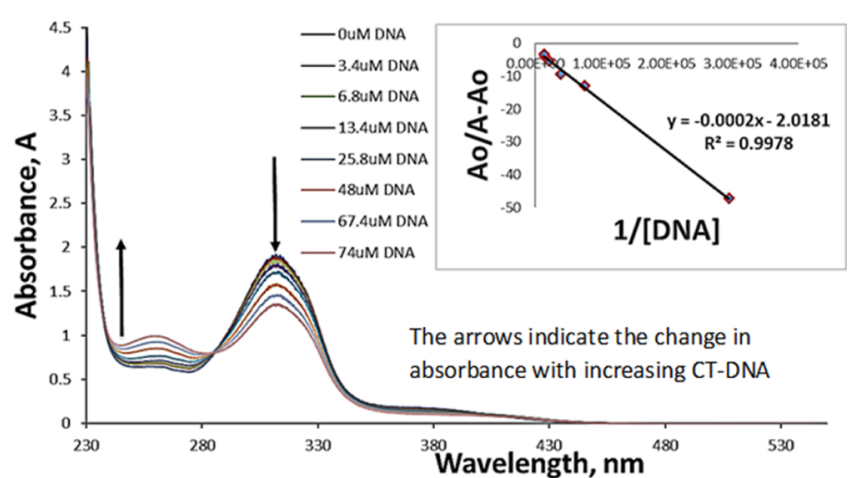

Figure 9. UV-vis absorption spectra for the CT-DNA interactions with C3.

cells but was highly toxic to the other four cell lines (HeLa, Hep-G2, PC-3, and MCF-12A). The different responses observed for the different cell lines may be attributed to genetic and transcriptional heterogeneity between the cell lines. Specific genetic mutations in these cells may have resulted increased susceptibility or conversely may result in increased resistance to the complexes. Further testing using whole proteome or genome analysis is needed to fully understand why the different cell lines responded in the way they did.

$\mathrm{C} \mathbf{1}$ and $\mathbf{C} 2$ only differ in structure by a $\mathrm{CH}_{3}$ - in $\mathrm{C} 1$ and a $\mathrm{Cl}-$ in $\mathbf{C 2}$ around the metal center. Because the $\mathrm{CH}_{3}$ group is a strong $\sigma$-bonding ligand with a stronger trans-influence compared to $\mathrm{Cl}$-, it causes the $\sigma$-bonding character of the $\mathrm{Pd}-\mathrm{Cl}$ bond in $\mathrm{Cl}$ to decrease. This means a better lability of the $\mathrm{Cl}$-trans to $\mathrm{CH}_{3}$ - in $\mathbf{C 1}$ compared to $\mathbf{C 2}$, which led to the
Table 2. Binding Constants and Gibbs Free Energy Values for the Complex-DNA Interactions

\begin{tabular}{cccc} 
complex & $\begin{array}{c}\text { mode of } \\
\text { binding }\end{array}$ & $\begin{array}{c}\text { binding constant } K_{\mathrm{b}} \\
\left(\mathrm{M}^{-1}\right)\end{array}$ & $\begin{array}{c}\text { gibbs free energy }(\Delta \mathrm{G}) \\
(\mathrm{kJ} \mathrm{mol})\end{array}$ \\
C1 & electrostatic & $1.6969 \times 10^{4}$ & -24.13 \\
C2 & intercalative & $1.5327 \times 10^{4}$ & -23.88 \\
C3 & intercalative & $1.0091 \times 10^{4}$ & -22.84 \\
C5 & intercalative & $8.049 \times 10^{4}$ & -27.99 \\
\hline
\end{tabular}

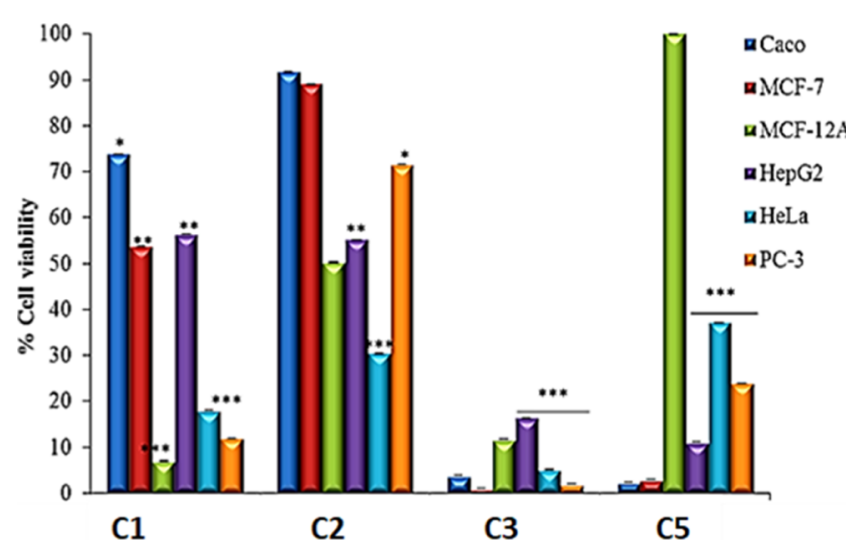

Figure 11. Screening of anticancer activity of Pd and Pt complexes (C1, C2, C3, and C5) against selected human cell lines. The cells were exposed to $100 \mu \mathrm{g} / \mathrm{mL}$ of compounds for $24 \mathrm{~h}$; cell viability was assessed by MTT assay. *indicates statistical significance at $p<0.05$ when compared to untreated cells, while $* *$ indicates $p<0.01$ and $* * * p<0.001$.

observed differences in their cytotoxicity profile. The $\mathrm{IC}_{50}$ values for the complexes $(\mathbf{C} 1, \mathbf{C} 2, \mathbf{C} 3$, and $\mathbf{C 5})$ are shown in

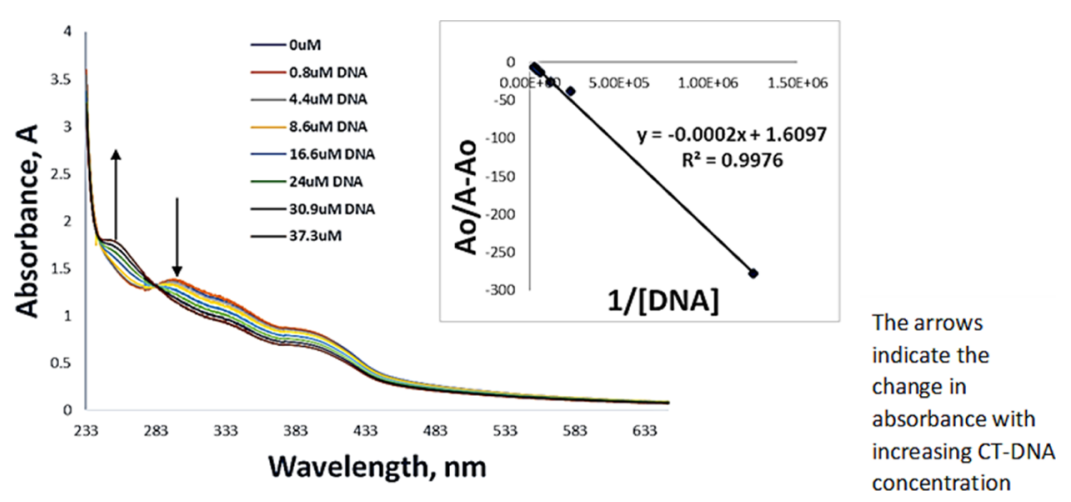

Figure 10. UV-vis absorption spectra for the CT-DNA Interactions with C5. 
Table 3. $\mathrm{IC}_{50}$ Values for the Ligands and Their Respective Complexes

\begin{tabular}{|c|c|c|c|c|c|}
\hline & \multicolumn{5}{|c|}{$[$ complex $](\mu \mathrm{g} / \mathrm{mL})$} \\
\hline & L1-3 Ligands & $\mathrm{Cl}$ & $\mathrm{C2}$ & $\mathrm{C} 3$ & C5 \\
\hline Caco-2 & $>100$ & $>100$ & $>100$ & $15.81 \pm 0.039$ & $16.63 \pm 0.006$ \\
\hline MCF-7 & $>100$ & $>100$ & $>100$ & $64.5 \pm 0.0171$ & $23.3 \pm 0.0031$ \\
\hline MCF-12A & $>100$ & $22.95 \pm 0.014$ & $53.5 \pm 0.0753$ & $24.9 \pm 0.0199$ & $>100$ \\
\hline HeLa & $>100$ & $66.62 \pm 0.051$ & $86.4 \pm 0.0286$ & $45.5 \pm 0.1665$ & $84.86 \pm 0.087$ \\
\hline Hep-G2 & $>100$ & $>100$ & $>100$ & $13.0 \pm 0.0294$ & $0.3 \pm 0.0054$ \\
\hline PC-3 & $>100$ & $25.1 \pm 0.0161$ & $>100$ & $20.9 \pm 0.0179$ & $29.5 \pm 0.0961$ \\
\hline
\end{tabular}
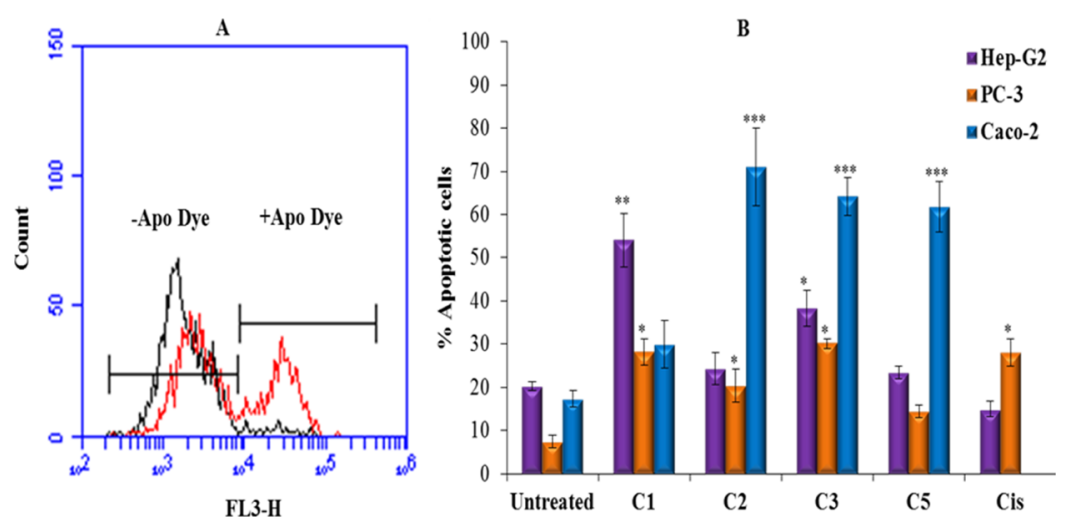

Figure 12. Apoptotic effects of organometallic complexes on human cancer cells.

Table 3. The ligands $(\mathbf{L} 1-\mathbf{3})$ were not cytotoxic at the highest concentration $(100 \mu \mathrm{g} / \mathrm{mL})$ tested. The complexes with cis geometry, C3 and C5, showed enhanced cytotoxicity compared to the trans-geometry complexes $\mathbf{C} 1$ and $\mathbf{C 2}$. The $\mathrm{IC}_{50}$ values varied significantly depending on the cell line and complex used. The $\mathrm{IC}_{50}$ value for C5 $(0.3 \pm 0.0054 \mu \mathrm{g} / \mathrm{mL})$ on the Hep-G2 cell line was the lowest $\mathrm{IC}_{50}$ value obtained. The $\mathrm{IC}_{50}$ values also demonstrate the selective toxicity of some of the complexes. While the $\mathrm{IC}_{50}$ values for $\mathbf{C} \mathbf{1}$ and $\mathbf{C} 2$ varied between 22 and $86 \mu \mathrm{g} / \mathrm{mL}$ for MCF-12A, HeLa, and PC-3 cells, the $\mathrm{IC}_{50}$ values for $\mathbf{C} 1$ and $\mathbf{C} 2$ were more than $100 \mu \mathrm{g} /$ $\mathrm{mL}$ for Caco-2, MCF-7, and Hep-G2 cells. Interestingly, C5 was highly toxic to MCF-7 cells with an $\mathrm{IC}_{50}$ value of $23.3 \pm$ $0.0031 \mu \mathrm{g} / \mathrm{mL}$, while the $\mathrm{IC}_{50}$ value for MCF-12A cells was more than $100 \mu \mathrm{g} / \mathrm{mL}$. This is significant because MCF-7 and MCF-12A are, respectively, cancerous and noncancerous cell lines from breast tissue. This demonstrates the selective toxicity of $\mathbf{C 5}$ toward MCF-7 breast cancer cells compared to the noncancerous breast cells.

The cells treated with these complexes demonstrated morphological changes, as shown in Figure S35, such as cell shrinking, loss of cell contact (detachment), membrane blebbing, and formation of apoptotic bodies, which are features that can be associated with apoptosis. ${ }^{45,46}$ To further confirm if the cytotoxic effects of the complexes are exerted through apoptosis, phosphatidyl serine (PS) externalization as one of the molecular markers of apoptosis was investigated using APOPercentage dye. PS is localized in the inner membrane of viable intact cells. Transmembrane lipid translocation during apoptosis results in the translocation of PS to the outside of the membrane. At this stage of apoptosis, apoptotic cells can be detected with the APOPercentage dye, which become entrapped within apoptotic cells. ${ }^{47}$

APOPercentage dye uptake was studied in selected cells (Hep-G2, PC-3, and Caco-2) treated with the complexes for $24 \mathrm{~h}$, and the number of apoptotic cells was quantified using a flow cytometer as described by Meyer et al. (2008); ${ }^{48}$ Figure 12 shows that the cell lines differed in their response to the complexes. Significantly higher levels of apoptosis were observed for the Caco-2 cell line when the cells were treated with C2, C3, and C5. Interestingly, C1 did not induce significant levels of apoptosis in Caco-2 cells. The Caco- 2 cell line was the only cell line that showed a significant increase in the percentage of apoptotic cells when treated with C5. Only $\mathbf{C} 1$ and $\mathbf{C} 3$ were able to induce significant levels of apoptosis in Hep-G2 cells, while $\mathbf{C} 1, \mathbf{C} 2$, and $\mathbf{C} \mathbf{3}$ induced significant levels of apoptosis in Hep-G2 cells PC3 cells. Cisplatin, which was used as a positive control, induced significant levels of apoptosis in PC3 cells but not Hep-G2 cells. The Caco-2 cell line was not treated with cisplatin.

The cells were exposed to $\mathrm{IC}_{50}$ of complexes $(100 \mu \mathrm{g} / \mathrm{mL})$ for $24 \mathrm{~h}$; apoptosis was assessed by the APOPercentage assay. Representative histograms (A) depict untreated (in black) and C3-treated (in red) Caco-2 cells. The cell population that is stained with the APOPercentage is labeled as +Apo Dye, and the cell population that are not stained is labeled as -Apo Dye. The bar graph in (B) shows the percentage apoptotic cells when Hep-G2, PC3, and Caco-2 cells are treated with the complexes. Treatment with Cisplatin (Cis) was used as a positive control. *indicates statistical significance at $p<0.05$ when compared to untreated cells, while $* *$ indicates $p<0.01$ and $* * * p<0.001$

\section{CONCLUSIONS}

New complexes based on pyrrole were synthesized and fully characterized. The structures were confirmed by elemental analysis, and the molecular structure and geometry of the $\mathrm{Pt}$ complex were confirmed by single-crystal X-ray crystallography.

Despite literature reports that the use of bulky ligands in trans-Pd complexes may confer increased cytotoxic activity, this was not observed in this study. This shows that bulky 
ligands, which shield the metal center to a point where it is not accessible for ligand substitution, may in fact reduce the efficacy of these compounds. The challenge is to balance the extent of shielding and the extent of accessibility of the metal center to bioligands. This conclusion is based on the bioactivity of $\mathbf{C 2}$ (trans-geometry with bulky ligands) compared to $\mathbf{C} 3$ (cis-geometry with unshielded metal centre). C2 showed selective cytotoxicity, while C3 displayed high cytotoxicity to all six cell lines tested in this study.

The Pt complex (C5), also of cis-conformation, showed enhanced and selective cytotoxicity and selectivity to cancer cells. This compound also demonstrated strong DNA intercalation activity. This suggests that $\mathbf{C 5}$ can be a viable candidate for cancer treatment and requires further in vivo tests.

\section{EXPERIMENTAL SECTION}

Standard inert atmosphere Schlenk line techniques under nitrogen or argon in the Laminar flow were used for all the synthetic procedures employed in this study. Reaction progress was monitored on a silica gel thin layer chromatography (Fluka) plates of $15 \mu \mathrm{m}$ particle size. Solvent was removed under vacuum via a liquid nitrogen trap, and samples are stored and dried as recommended and distilled prior to use. All reagents utilized in synthesis were of analytical grade; they were purchased from Sigma-Aldrich or Merck and used without further modifications.

Determination of melting points was performed on open glass capillaries using the SMP-10 instrument. FTIR spectra were run using a PerkinElmer Spectrum 100 Series FTIR instrument on the range $4000-400 \mathrm{~cm}^{-1}$ using $\mathrm{KBr}$ pellets. Proton nuclear magnetic resonance $\left({ }^{1} \mathrm{H}\right.$ NMR) spectra were run on a Bruker $400 \mathrm{MHz}$ spectrometer available at the University of Western Cape, South Africa. The chemical shifts were measured in ppm relative to TMS standard. Elemental analysis was performed on Server 1112 series Elemental Analyzer at Stellenbosch University. UV-vis spectra were recorded in DMSO at a range of $200-800 \mathrm{~nm}$ using Nicolet evolution 100 spectrophotometer from Thermo Electron Corporation, and the data were analyzed using VisionPro software. Cyclic voltammetry studies were performed using the PalmerScan 3 instrument equipped with glassy carbon electrodes as working electrodes, $\mathrm{Ag} / \mathrm{AgCl}$ as the reference electrode, and platinum wire as the counter electrode, scan range of -1.8 to +1.8 , and a scan rate of $200 \mathrm{mV} / \mathrm{s}$. The supporting electrolyte was $5 \mathrm{~mL}$ of $10 \mathrm{mMol}$ phosphate-buffered saline (PBS) buffer at $\mathrm{pH}$ 7. Single-crystal X-ray crystallography was performed on Bruker SMART CCD APEXII area-detector diffractometer available at Rutgers University, USA.

Synthesis of the Ligands and Complexes. (E)- $\mathrm{N}-((1 \mathrm{H}-$ Pyrrol-2-yl)methylene) (Phenyl) Methanamine (L1). The ligand was synthesized using $0.3882 \mathrm{~g}(4 \mathrm{mmol})$ Pyrrole-2carbaldehyde and $440 \mu \mathrm{L}(4 \mathrm{mmol})$ benzylamine in dry methanol and refluxed overnight. The solvent was rotavaped to dryness, and the product was obtained as orange powder. It was recrystallized in $\mathrm{DCM} / \mathrm{Et}_{2} \mathrm{O}$ and kept in fridge overnight for complete precipitation. The mother liquor was filtered off, and the product dried under vacuum. Crystals suitable for Xray crystallography were grown by slow diffusion of hexane into DCM, yielding light brown crystals. Yield: 95\% mp 110$112^{\circ} \mathrm{C}$. FTIR $\left(\mathrm{KBr} \mathrm{cm}^{-1}\right) ; 1636,(\mathrm{C}=\mathrm{N}) ; 2829\left(\mathrm{sp}^{3}-\mathrm{C}-\mathrm{H}\right)$; 2888 (-C-H benzene), 3369, (-N-H). ${ }^{1} \mathrm{H}$ NMR (400 $\mathrm{MHz}, \mathrm{CDCL}_{3}, \delta$-ppm): $\delta 8.15(\mathrm{~s}, 1 \mathrm{H}), 7.24-7.37(\mathrm{~m}, 5 \mathrm{H})$, $6.90(\mathrm{~s}, 1 \mathrm{H}), 6.53(\mathrm{dd}, J=1.22,3.55 \mathrm{~Hz}, 1 \mathrm{H}), 6.22-6.27(\mathrm{~m}$, $1 \mathrm{H}), 4.71(\mathrm{~s}, 2 \mathrm{H}) .{ }^{13} \mathrm{C} \mathrm{NMR}\left(400 \mathrm{MHz}, \mathrm{CDCL}_{3}\right): \delta 152.35$ (imine $\mathrm{C}=\mathrm{N}), 137.04\left(\mathrm{C}_{2} \underline{\mathrm{C}}-\mathrm{N}\right.$ pyrrole $), 128.55,128.19$, 127.98, 127.56, 127.07, 120.23 (CE-N pyrrole), 109.88, 88.93, 55.29 $\left(\mathrm{CH}_{2}\right)$. Molecular weight (Calcd); 184.2371, ESI-MS $(m / z):[\mathrm{M}+\mathrm{H}]^{+}$(obtained): 184.2. Molecular formula; $\mathrm{C}_{12} \mathrm{H}_{12} \mathrm{~N}_{2}$, elemental analysis; Calcd (obtained) $\mathrm{N}$, 15.21 (15.63); C, 74.2 (74.46); H, 6.8 (7.0)

(E)-N-((1H-Pyrrol-2-yl)methylene) (Furan-2-yl) Methanamine (L2). The ligand was synthesized as for the previous ligand using $0.4853 \mathrm{~g}(5 \mathrm{mmol})$ pyrrole-2-carbaldehyde and $450 \mu \mathrm{L}(5 \mathrm{mmol})$ furfurylamine with $\mathrm{MgSO}_{4}$ and stirred in room temperature for $18 \mathrm{~h}$. Orange powder turned to brown. It was recrystallized from DCM with ether. Yield: $0.8166 \mathrm{~g}$ (94\%). mp $86-89^{\circ} \mathrm{C}$. Soluble in methanol, chloroform, DCM, $\mathrm{Et}_{2} \mathrm{O}$.

FTIR $\left(\mathrm{KBr} \nu^{-1}\right) ; 1644, \mathrm{C}=\mathrm{N}$ (stretch); $2868 \mathrm{sp}^{3}-\mathrm{C}-\mathrm{H}$ stretch; $2975-\mathrm{C}-\mathrm{H}$ (aromatic) stretch, 3177; N-H stretch. ${ }^{1} \mathrm{H}$ NMR $\left(400 \mathrm{MHz}, \mathrm{CDCl}_{3}\right): \delta 8.12(\mathrm{~s}, 1 \mathrm{H}), 7.38(\mathrm{~s}, 1 \mathrm{H})$, $6.89(\mathrm{~s}, 1 \mathrm{H}), 6.53$ (br s, $1 \mathrm{H}), 6.34(\mathrm{~d}, J=3.06 \mathrm{~Hz}, 1 \mathrm{H}), 6.24$ $(\mathrm{s}, 2 \mathrm{H}), 4.67(\mathrm{~s}, 2 \mathrm{H}) .{ }^{13} \mathrm{C}$ NMR (400 MHz, Chloroform- $d$ ): $\delta$ 153.19 ( $\underline{\mathrm{C}=\mathrm{N}}$ imine), 153.09 ( $\mathrm{C}_{2} \underline{\mathrm{C}}-\mathrm{O}$ furan), 152.68 (C$\underline{\mathrm{C}}-\mathrm{O}$ furan $), 149.24 \quad\left(\mathrm{C}_{2} \underline{\mathrm{C}}=\mathrm{N}\right.$ pyrrole $), 142.21 \quad(\mathrm{C} \underline{\mathrm{C}}-\mathrm{N}$ pyrrole), 124.79, 122.09, 120.07, 114.97, $56.47\left(\mathrm{CH}_{2}\right)$

Molecular weight (Calcd); 174.1992, ESI-MS $(\mathrm{m} / z):[\mathrm{M}+$ $\mathrm{H}]^{+}$(obtained); 174. Molecular formula; $\mathrm{C}_{10} \mathrm{H}_{10} \mathrm{~N}_{2} \mathrm{O}$, elemental analysis; Calcd (obtained) C, 68.95(68.61); $\mathrm{H}$, 5.79(6.2); N, 16.08(16.47).

(E)-N-((1H-Pyrrol-2-yl)methylene) (Pyridin-2-yl) Methanamine (L3). The ligand was synthesized as for the previous ligands using $0.3882 \mathrm{~g}(4 \mathrm{mmol})$ pyrrole-2-carbaldehyde and 4 mmol $(420 \mu \mathrm{L})$ 2-methylamino pyridine (picolyamine). The reaction mixture turned yellow during reflux. The solvent was evaporated to dryness under rotavap, and the product was isolated as a paste. It was recrystallized in $\mathrm{DCM} / \mathrm{Et}_{2} \mathrm{O}$ and kept in fridge overnight to complete precipitation; mother liquor was filtered off, and the product dried under vacuum. Yield: 94\%. mp 96-99 ${ }^{\circ}$ C. Soluble in methanol, chloroform, DCM, $\mathrm{Et}_{2} \mathrm{O}$.

FTIR $\left(\mathrm{KBr} \nu^{-1}\right) ; 1632, \mathrm{C}=\mathrm{N}$ (stretch); $2962 \mathrm{sp}^{3}-\mathrm{C}-\mathrm{H}$ stretch; $2847-\mathrm{C}-\mathrm{H}$ (aromatic) stretch, 3080; N-H stretch. ${ }^{1} \mathrm{H}$ NMR $\left(400 \mathrm{MHz}, \mathrm{CDCL}_{3}\right): \delta 8.56(\mathrm{~d}, J=4.16 \mathrm{~Hz}, 1 \mathrm{H})$, $8.24(\mathrm{~s}, 1 \mathrm{H}), 7.61(\mathrm{dt}, J=1.71,7.64 \mathrm{~Hz}, 1 \mathrm{H}), 7.31(\mathrm{~d}, J=7.82$ $\mathrm{Hz}, 1 \mathrm{H}), 7.15$ (dd, $J=5.32,6.91 \mathrm{~Hz}, 1 \mathrm{H}), 6.83(\mathrm{~s}, 1 \mathrm{H}), 6.54$ $(\mathrm{dd}, J=1.10,3.55 \mathrm{~Hz}, 2 \mathrm{H}), 6.23(\mathrm{dd}, J=2.81,3.42 \mathrm{~Hz}, 1 \mathrm{H})$, $4.86(\mathrm{~s}, 2 \mathrm{H}) .{ }^{13} \mathrm{C} \mathrm{NMR}\left(400 \mathrm{MHz}, \mathrm{CDCL}_{3}\right): \delta 160.03$ $\left(\mathrm{C}_{2} \underline{\mathrm{C}}=\mathrm{N}\right.$ pyridine $\left.)\right), 153.67(\underline{\mathrm{C}}=\mathrm{N}$ imine $), 150.50,149.30$, $142.99,136.62\left(\mathrm{C}_{2} \underline{\mathrm{C}}-\mathrm{N}\right.$ pyrrole $), 131.59,130.08,119.80$ (Cㅡ-N pyrrole), 114.87, 111.11, $66.18\left(\underline{\mathrm{CH}}_{2}\right)$.

Molecular weight (Calcd); 185.2251, ESI-MS $(\mathrm{m} / z)[\mathrm{M}-$ $\mathrm{H}]^{+}$183.1. Molecular formula; $\mathrm{C}_{11} \mathrm{H}_{11} \mathrm{~N}_{3}$. Elemental analysis Calcd (obtained); N, 22.69(22.45); C, 70.33(69.38); H, 5.99(5.6).

Trans-Chloridobis[(pyrrolymethylidene) (Benz-2-yl-methyl) Amine- $\kappa N$ ] Methylpalladium(II) (C1). To a stirring solution of $92 \mathrm{mg}(0.5 \mathrm{mmol}) \mathbf{L 1}$ in $\mathrm{CH}_{2} \mathrm{Cl}_{2}$ under nitrogen was added dropwise a solution of $0.25 \mathrm{mmol}(66 \mathrm{mg}) \mathrm{Pd}(\mathrm{COD}) \mathrm{ClMe}$ in $\mathrm{CH}_{2} \mathrm{Cl}_{2}$. The solution turned green, and stirring was sustained overnight at room temperature conditions. The solution was reduced under vacuum to about $1 \mathrm{~mL}$, and hexane was added in excess to precipitate out the product. The mixture was kept in fridge overnight to allow complete precipitation; liquor was filtered off, and the precipitate was washed with more hexane, 
filtered, and dried in inert conditions under vacuum. Yield: $52 \%$, mp $216{ }^{\circ} \mathrm{C}$ (decompose). FTIR $\left(\mathrm{KBr} \mathrm{cm}{ }^{-1}\right) ; 3025$, (aromatic C-H); 2937, (aliphatic $\mathrm{C}-\mathrm{H}) ; 1602,(\mathrm{C}=\mathrm{N}) .{ }^{1} \mathrm{H}$ $\operatorname{NMR}\left(400 \mathrm{MHz}, \mathrm{CDCL}_{3}\right): \delta 7.78(\mathrm{~s}, 2 \mathrm{H}), 7.41(\mathrm{~m}, 5 \mathrm{H}), 7.29$ (m, 5H), 6.92 (s, 2H), 6.64 (s, 4H), 6.09 (br. s., 2H), 4.93 (s, $4 \mathrm{H}), 1.58$ (br. s., $3 \mathrm{H}) \cdot{ }^{13} \mathrm{C} \mathrm{NMR}\left(101 \mathrm{MHz}, \mathrm{CDCL}_{3}\right): \delta=$ $162.8,139.5,137.5,136.7,129.0,127.8,117.7,111.0,61.3$. Molecular weight (Calcd); 525.38, molecular formula; liquid chromatography-mass spectrometry $(\mathrm{LC}-\mathrm{MS})(\mathrm{m} / \mathrm{z}):[\mathrm{M}+$ $\mathrm{H}]^{+}$(obtained) 525.30; $\mathrm{C}_{25} \mathrm{H}_{27} \mathrm{ClN}_{4} \mathrm{Pd}$, elemental analysis; Calcd (obtained); N, 110.7 (11.3); C, 55.2 (55.79); H, 5.2 (5.1).

Trans-Dichloridobis[(pyrrolymethylidene) (furan-2-ylmethyl) Amine-kN] Methylpalladium(II) (C2). The complex was synthesized for the previous one using $174 \mathrm{mg}(1 \mathrm{mmol})$ of $\mathbf{L} 3$ and $144 \mathrm{mg}(0.5 \mathrm{mmol}) \mathrm{Pd}(\mathrm{COD}) \mathrm{Cl}_{2}$. The mixture formed an orange solution which was reduced to about $1 \mathrm{~mL}$ by vacuum, and the product was recrystallized with diethyl ether. It was filtered, washed with $5 \mathrm{~mL} \mathrm{Et}_{2} \mathrm{O}$ and further with $2 \times 5 \mathrm{~mL}$ hexane, and dried under vacuum to afford an orange product. Yield: $60 \mathrm{mg}, 23 \%$. The complex was analyzed by FTIR, UV-vis, and elemental analysis. FTIR $\left(\mathrm{KBr} \mathrm{cm}^{-1}\right)$ 3117, (aromatic C-H); 3015, (aliphatic $\mathrm{C}-\mathrm{H}) ; 1662,(\mathrm{C}=$ N). ${ }^{1} \mathrm{H}$ NMR (400 MHz, $\left.\mathrm{CDCl}_{3}\right): \delta 7.69(\mathrm{~s}, 1 \mathrm{H}), 7.54$ (br s, 2H), 7.13 (br s, $1 \mathrm{H}), 6.46$ (br s, $3 \mathrm{H}), 4.81$ (br s, $2 \mathrm{H}), 3.49$ (s, $2 \mathrm{H}), 1.59(\mathrm{~s}, 3 \mathrm{H}), 1.21(\mathrm{~s}, 3 \mathrm{H})$. Molecular formula; $\mathrm{C}_{20} \mathrm{H}_{20} \mathrm{Cl}_{2} \mathrm{~N}_{4} \mathrm{O}_{2} \mathrm{Pd}$, molecular weight (Calcd); 525.72, LCMS $(m / z):[\mathrm{M}+\mathrm{H}]^{+}$(obtained) 525.29. Elemental analysis; Calcd (obtained); C, 45.69(45.84); H, 2.84(2.79); N, 5.30(5.65).

cis-Dichlorido[(pyrrolymethylidene) (Pyridyl-2-yl-methyl) Amine N,N] Pd(II) (C3). The complex was synthesized as for the previous one using $93 \mathrm{mg}(0.5 \mathrm{mmol}) \mathrm{L} 3$ and $0.5 \mathrm{mmol}$ $(144 \mathrm{mg}) \mathrm{Pd}(\mathrm{COD}) \mathrm{Cl}_{2}$. The product precipitated immediately, and the mixture was stirred overnight after which the precipitation was deemed complete. It was filtered, washed with $5 \mathrm{~mL} \mathrm{Et}{ }_{2} \mathrm{O}$ and further with $2 \times 5 \mathrm{~mL}$ hexane, and dried under vacuum to afford a gray product. The compound was analyzed by FTIR, UV-vis, and elemental analysis. Yield: $90 \%$. mp $250{ }^{\circ} \mathrm{C}$ (decompose). FTIR $\left(\mathrm{KBr} \mathrm{cm}{ }^{-1}\right) 1610, \mathrm{C}=\mathrm{N}$ (stretch); 1576, $\mathrm{C}=\mathrm{N}$ (aromatic). ${ }^{1} \mathrm{H}$ NMR (400 MHz, $\left.\mathrm{CDCl}_{3}\right): \delta 7.44(\mathrm{~d}, 1 \mathrm{H}), 7.26(\mathrm{~s}, 1 \mathrm{H}), 6.44(\mathrm{~m}, 1 \mathrm{H}), 6.31(\mathrm{~m}$, $2 \mathrm{H}), 5.30(\mathrm{~m}, 1 \mathrm{H}), 4.81(\mathrm{~m}, 1 \mathrm{H}), 3.49(\mathrm{~m}, 1 \mathrm{H}), 1.57(\mathrm{~d}, 1 \mathrm{H})$, $1.21(\mathrm{~s}, 2 \mathrm{H})$. Molecular formula; $\mathrm{C}_{11} \mathrm{H}_{11} \mathrm{Cl}_{2} \mathrm{~N}_{3} \mathrm{Pd}$, Molecular weight (Calcd); 362.55; LC-MS $(\mathrm{m} / z):[\mathrm{M}+\mathrm{H}]^{+}$(obtained) 362.04. Elemental analysis Calcd (obtained); C, 36.4(36.5); H, 3.1(3.5); N, 11.6(11.2).

Pt Complex $\left[\mathrm{Pt}_{2}(\mu-\mathrm{Cl})_{2}(\mathrm{dmsO})_{2}(\mathrm{~L} 1)_{2}\right]$ (C5) and $\mathrm{PtCl}_{2}$ dmsoL 1 (C5). The platinum complex $\mathrm{C5}$ was obtained by reaction of $\mathbf{L l}$ with $\mathrm{Pt}(\mathrm{DMSO})_{2} \mathrm{Cl}_{2}$ at room temperature. Into a stirring solution of $42 \mathrm{mg}(0.125 \mathrm{mmol}) \mathrm{Pt}(\mathrm{DMSO})_{2} \mathrm{Cl}_{2}$ in $15 \mathrm{~mL}$ DCM, $0.125 \mathrm{mmol}(23 \mathrm{mg}) \mathbf{L 1}$ in $5 \mathrm{~mL} \mathrm{DCM}$ was added dropwise using a nitrogen-filled syringe. Stirring was continued overnight, evaporated under vacuum to yield a yellow precipitate of C5 which was filtered and dried under vacuum. Yield: $65 \%$. FTIR $\left(\mathrm{KBr} \mathrm{cm}^{-1}\right)$ 3300, $\left(2^{\circ}\right.$ amine $\mathrm{N}-\mathrm{H}$ for pyrrole); 3130, (aromatic $\mathrm{C}-\mathrm{H})$; 3016, (aliphatic $\mathrm{C}-\mathrm{H}$ ); 1631, $(\mathrm{C}=\mathrm{N}) .{ }^{1} \mathrm{H}$ NMR $\left(400 \mathrm{MHz}, \mathrm{CDCl}_{3}\right): \delta 7.78-7.85$ (m, 2H), $7.26(\mathrm{~s}, 10 \mathrm{H}), 6.90-7.01(\mathrm{~m}, 4 \mathrm{H}), 6.55-6.61(\mathrm{~m}$, $2 \mathrm{H}), 3.43-3.52(\mathrm{~m}, 2 \mathrm{H}), 2.17(\mathrm{~s}, 4 \mathrm{H}), 1.56(\mathrm{~s}, 12 \mathrm{H})$. Elemental analysis; Calcd (obtained); C, 34.11 (34.15); H, 3.68 (3.70); N, 5.68 (5.69); S, 6.51 (6.50). Crystals suitable for $\mathrm{X}$-ray crystallography were obtained by slow evaporation of the
DCM solution and were obtained as light-yellow crystals of C5. ${ }^{1} \mathrm{H}$ NMR (400 MHz, DMSO- $d_{6}$ ): $\delta 8.72$ (br. s., $1 \mathrm{H}$ ), 8.44 (s, 1H), 7.45 (s, 5H), 6.45 (br. s., $1 \mathrm{H}), 5.11$ (s, $1 \mathrm{H}), 4.92$ (s, $1 \mathrm{H}), 3.35(\mathrm{~s}, 2 \mathrm{H}), 2.54(\mathrm{~s}, 6 \mathrm{H})$. Molecular weight (Calcd); 528.3 LC-MS $(\mathrm{m} / z):[\mathrm{M}+\mathrm{H}]^{+}$(obtained), 530.07.

Partition Coefficient. The partition coefficient as the $\log P$ value was determined for $\mathbf{C 1}-\mathbf{C 5}$ by the shake-flask method. The values were determined by partitioning the complexes between $10 \mathrm{~mL}$ of deionized water (the medium inside and outside the cells) and $10 \mathrm{~mL}$ of $99 \%$-octanol (a model of the lipid bilayer of the cell membrane) and stirring for $48 \mathrm{~h}$. The two layers were first presaturated with each other to avoid solubility-induced volume changes during the extraction step. ${ }^{49}$ Before extraction, the absorbance of the initial stock was determined after appropriate dilutions.

The mixture was then left to settle for $24 \mathrm{~h}$ after which $3 \mathrm{~mL}$ aliquots were taken from each layer and centrifuged for $2 \mathrm{~h}$ at $7000 \mathrm{rpm}$ using the Minispin Epperdorf centrifuge. The UVvis absorbance for the two layers was taken after appropriately diluting the layers. ${ }^{50}$ Absorbance was read using a 96-well microplate on a POLARstar Omega microplate reader instrument from BMG Labtech. The partition coefficient was calculated as $\log \left(C_{\mathrm{O}} / C_{\mathrm{W}}\right)$, where $C_{\mathrm{O}}$ is the concentration in the oil layer, and $C_{\mathrm{W}}$ is the concentration in the water layer.

Electrochemical Properties of the Pd Complexes. Electrochemical studies in solution were performed on two of the complexes (C3 and C4) using the PalmerScan3 instrument equipped with glassy carbon electrodes as working electrodes, $\mathrm{Ag} / \mathrm{AgCl}$ as the reference electrode and platinum wire as the counter electrode. A scan range of -1.8 to +1.8 and a scan rate of $200 \mathrm{mV} / \mathrm{s}$ were used. The supporting electrolyte was $5 \mathrm{~mL}$ of $10 \mathrm{mMol}$ PBS buffer at $\mathrm{pH}$ 7.0.

Single-Crystal X-ray Analysis. Crystals suitable for X-ray crystallography were grown by slow diffusion of hexane into DCM which gave crystal for $\mathbf{L} \mathbf{1}$ or by slow evaporation of a DCM solution of the ligand for $\mathbf{L} 2$ and the platinum complex, C5. X-ray crystallography was performed on a Bruker SMART CCD APEXII area-detector diffractometer and was kept at $100.03 \mathrm{~K}$ during data collection. Using Olex2 software, ${ }^{51}$ the structure was solved with the ShelXS-1997 ${ }^{52}$ structure solution program using Direct Methods and refined with the Olex2 refinement package. ${ }^{53}$

Evaluation of the Bioactivity of the Organometallic Compounds. DNA Binding Studies. This was done by UV-vis spectroscopy by serial titrations of CT-DNA into a fixed concentration of the complexes in a quartz cuvette. UV-vis readings were taken at increasing amounts of DNA and allowing for $10 \mathrm{~min}$ equilibration time after each addition. The binding kinetics for the complex-DNA interaction was then determined from the intrinsic binding constant, $K_{\mathrm{b}}$, by plots of the Benesi-Hildebrand host-guest equation. ${ }^{54}$ From the $K_{\mathrm{b}}$ values, Gibbs free energy changes $(\Delta G)$ for the complexDNA interactions were then calculated and compared with known DNA intercalators.

Effect of Compounds on Cancer Cells. Cytotoxicity of the compounds was tested against human cell lines: Caco-2 (colon), HeLa (Cervical), Hep-G2 (Hepatocellular Carcino$\mathrm{ma} /$ liver cancer), MCF-7 (breast cancer), PC-3 (prostate), and MCF-12A (non-cancer breast) cells. The cells were cultured in their respective media supplemented with $10 \%$ foetal bovine serum (FBS) and $1 \%$ pen-strep cocktail comprised of streptomycin $(100 \mu \mathrm{g} / \mathrm{mL})$ and penicillin $(100 \mathrm{U} / \mathrm{mL})$. Caco-2, HeLa, Hep-G2, and MCF-7 cell lines were cultured 
in Dulbecco's modified Eagle medium (DMEM); MCF-12A in DMEM-F12 containing insulin, EGF, and hydrocortisone, while PC-3 cells were cultured RPMI-1640 media. The cells were incubated at $37{ }^{\circ} \mathrm{C}$ in a $5 \%$ humidified $\mathrm{CO}_{2}$ incubator (Labotech, South Africa).

The cells were seeded at $1 \times 10^{5}$ cells $/ \mathrm{mL}$ density in a 96well plate and incubated at $37{ }^{\circ} \mathrm{C}$ for $24 \mathrm{~h}$. The cells were treated with varying concentrations of extracts $(0-100 \mu \mathrm{g}$ / $\mathrm{mL}$ ) for $24 \mathrm{~h}$. Cytotoxicity of the compounds was assessed by MTT assay following manufacturer's instructions. After treatment, $10 \mu \mathrm{L}$ of $5 \mathrm{mg} / \mathrm{mL}$ MTT (Sigma, USA) was added to each well and the plates were incubated at $37^{\circ} \mathrm{C}$ for 3 h. The insoluble formazan crystals were solubilized by adding $100 \mu \mathrm{L}$ of DMSO. The reduction of MTT was read at $570 \mathrm{~nm}$ using the POLARStar Omega plate reader. Cell viability was calculated using eq 5 given below

$$
\begin{aligned}
\% \text { cell viability }= & \frac{\text { average absorbance of treated cells }}{\text { average absorbance of control }} \\
& \times 100
\end{aligned}
$$

The half-maximal cytotoxic concentration $\left(\mathrm{IC}_{50}\right)$ on each cell line was estimated using GraphPad Prism software version 5 (GraphPad Software, California, USA).

APOPercentage Apoptosis Assay. APOPercentage assay (Biocolor Ltd.) was performed following a protocol described by Alpuche-Aviles et al. (2018). ${ }^{33}$ Briefly, selected cell lines (Hep-G2, PC-3, and Caco-2) were seeded in 12 well cell culture plates at a density of $1 \times 10^{5}$ cells $/ \mathrm{mL}$ and treated using concentrations equivalent to the $\mathrm{IC}_{50}$ values obtained using the MTT assay. After treatment, the morphological changes in the cells were observed under inverted contrast microscope (EVOS XL Core microscope; Thermo Fisher Scientific, Germany) at $10 \times$ magnification. The cells were then trypsinized and stained with APOPercentage dye. The cells staining positive for the APOPercentage dye were quantified using a Becton Dickinson (BD) Accuri C6 Flow cytometer (BD Biosciences Pharmingen, San Diego, CA, USA). A minimum of 10,000 events per sample was acquired, and the data were analyzed using the $\mathrm{BD}$ Accuri software (BD Biosciences).

Statistical Analyses. Statistical analyses for MTT and APOPercentage Apoptosis data were analyzed using Graph pad prism 6.0. The data were presented as means $\pm S$ according to the one-way ANOVA test and student $t$-test. A $p$ value of $<0.05$ was considered to be of statistical significance and represented by an asterisk $(*)$. ${ }^{*} p<0.05, * * p<0.01$, and $* * * p<0.001$.

\section{ASSOCIATED CONTENT}

\section{(s) Supporting Information}

The Supporting Information is available free of charge at https://pubs.acs.org/doi/10.1021/acsomega.0c00360.

FTIR spectra (Figures S1-S7); ${ }^{1}$ HNMR spectra (Figures S8-S13); ${ }^{13}$ CNMR spectra (Figures S14-S18); mass spectra supplementary data (Figures S19-25); UV/Vis spectra (Figures S26-S32); and check CIF data for L1 (labelled PC-BA), L2 (labelled PC-O), and C5 (labelled PC-BA-Pt) (PDF)

CheckCIF report for Ligand L1 (CIF)

CheckCIF report for Ligand L2: Alert levels A and B explained (CIF)

CheckCIF report for Complex C5 (CIF)

\section{AUTHOR INFORMATION}

\section{Corresponding Author}

Martin O. Onani - Organometallics and Nanomaterials, Department of Chemistry, University of the Western Cape, Bellville 7535, South Africa; (1) orcid.org/0000-0002-47353669; Email: monani@uwc.ac.za

\section{Authors}

Simon N. Mbugua - Organometallics and Nanomaterials, Department of Chemistry, University of the Western Cape, Bellville 7535, South Africa; Department of Chemistry, University of Nairobi, Nairobi 00100, Kenya

Nicole R. S. Sibuyi - Department of Science and Technology/ Mintek Nanotechnology Innovation Centre (DST/Mintek NIC), Biolabels Node, Department of Biotechnology, University of the Western Cape, Bellville 7535, South Africa; 이이. org/ 0000-0001-7175-5388

Lydia W. Njenga - Department of Chemistry, University of Nairobi, Nairobi 00100, Kenya

Ruth A. Odhiambo - Department of Chemistry, University of Nairobi, Nairobi 00100, Kenya

Shem O. Wandiga - Department of Chemistry, University of Nairobi, Nairobi 00100, Kenya

Mervin Meyer - Department of Science and Technology/Mintek Nanotechnology Innovation Centre (DST/Mintek NIC), Biolabels Node, Department of Biotechnology, University of the Western Cape, Bellville 7535, South Africa

Roger A. Lalancette - Rutgers, Department of Chemistry, Rutgers State University, Newark, New Jersey 07102, United States; ○ orcid.org/0000-0002-3470-532X

Complete contact information is available at: https://pubs.acs.org/10.1021/acsomega.0c00360

\section{Notes}

The authors declare no competing financial interest.

\section{ACKNOWLEDGMENTS}

The authors gratefully acknowledge the International Science Program (ISP) Uppsala, Sweden under the KEN-01 project, and the NRF South Africa (CSUR160323161066) for funding this research; NIC Biolabels Node (Department of Biotechnology, UWC), University of Nairobi, for support and guidance in this work; and the Organometallics and Nanomaterials group (Department of Chemical Sciences, UWC), South Africa, where this work was carried out.

\section{REFERENCES}

(1) Siegel, R. L.; Miller, K.; Jemal, A. Cancer Statistics, 2018. CaCancer J. Clin. 2018, 68, 7-30.

(2) Ferlay, J.; Colombet, M.; Soerjomataram, I.; Mathers, C.; Parkin, D. M.; Piñeros, M.; Znaor, A.; Bray, F. : Estimating The Global Cancer Incidence And Mortality In 2018: Globocan Sources And Methods. Int. J. Canc. 2019, 144, 1941-1953.

(3) Nagaraju, G. P.; Srivani, G.; Dariya, B.; Chalikonda, G.; Farran, B.; Behera, S. K.; Alam, A.; Kamal, M. A. Nanoparticles Guided Drug Delivery and Imaging in Gastric Cancer. Semin. Cancer Biol. 2020, DOI: 10.1016/j.semcancer.2020.01.006.

(4) Misirlic-Dencic, S.; Poljarevic, J.; Isakovic, A. M.; Sabo, T.; Markovic, I.; Trajkovic, V. Current Development Of Metal Complexes With Diamine Ligands As Potential Anticancer Agents. Curr. Med. Chem. 2020, 27, 380-410.

(5) El-Razek, S. E. A.; El-Gamasy, S. M.; Hassan, M.; Abdel-Aziz, M. S.; Nasr, S. M. Transition Metal Complexes Of A Multidentate Schiff Base Ligand Containing Guanidine Moiety: Synthesis, Character- 
ization, Anti-Cancer Effect, And Anti-Microbial Activity. J. Mol. Struct. 2020, 1203, 127381.

(6) Hallek, M. Chronic Lymphocytic Leukemia: 2020 Update On Diagnosis, Risk Stratification And Treatment. Am. J. Hematol. 2019, 94, 1266-1287.

(7) Ginsburg, O.; Bray, F.; Coleman, M. P.; Vanderpuye, V.; Eniu, A.; Kotha, S. R.; Sarker, M.; Huong, T. T.; Allemani, C.; Dvaladze, A.; Gralow, J.; Yeates, K.; Taylor, C.; Oomman, N.; Krishnan, S.; Sullivan, R.; Kombe, D.; Blas, M. M.; Parham, G.; Kassami, N.; Conteh, L. The Global Burden Of Women's Cancers: A Grand Challenge In Global Health. Lancet 2017, 389, 847-860.

(8) Ward, R. J.; Crichton, R. R. Essential Metals In Medicine: Therapeutic Use And Toxicity Of Metal Ions In The Clinic. Met. Ions Life Sci. 2019, 19, 87-122.

(9) Sánchez-López, E.; Gomes, D.; Esteruelas, G.; Bonilla, L.; LopezMachado, A. L.; Galindo, R.; Cano, A.; Espina, M.; Ettcheto, M.; Camins, A.; Silva, A. M.; Durazzo, A.; Santini, A.; Garcia, M. L.; Souto, E. B. Metal-Based Nanoparticles As Antimicrobial Agents: An Overview. Nanomaterials 2020, 10, 292.

(10) Ali, I.; Lone, M.; Al-Othman, Z.; Al-Warthan, A.; Sanagi, M. Heterocyclic Scaffolds: Centrality In Anticancer Drug Development. Curr. Drug Targets 2015, 16, 711-734.

(11) Özdemir, İ.; Çiftçi, O.; Evren, E.; Gürbüz, N.; Kaloğlu, N.; Başak Türkmen, N.; Yaşar, Ş.; Üstün, E.; Hamdi, N.; Mansour, L.; Özdemir, I. Synthesis, Characterization And Antitumor Properties Of Novel Silver (I) And Gold (I) N-Heterocyclic Carbene Complexes. Inorg. Chim. Acta 2020, 506, 119530.

(12) Sreenivasulu, R.; Tej, M. B.; Jadav, S. S.; Sujitha, P.; Kumar, C. G.; Raju, R. R. Synthesis, Anticancer Evaluation And Molecular Docking Studies Of 2, 5-Bis (Indolyl)-1, 3, 4-Oxadiazoles, Nortopsentin Analogues. J. Mol. Struct. 2020, 1208, 127875.

(13) Apetrei, R.-M.; Camurlu, P. Functional Platforms For (Bio) Sensing: Thiophene-Pyrrole Hybrid Polymers. J. Electrochem. Soc. 2020, 167, 037557.

(14) Bavadi, M.; Niknam, K.; Shahraki, O. Novel Pyrrole Derivatives Bearing Sulfonamide Groups: Synthesis In Vitro Cytotoxicity Evaluation, Molecular Docking And Dft Study. J. Mol. Struct. 2017, $1146,242-253$

(15) Saeed, H.; Sreedharan, S.; Thomas, JA Photoactive Metal Complexes That Bind Dna And Other Biomolecules As Cell Probes, Therapeutics, And Theranostics. Chem. Commun. 2020, 56, 1464.

(16) Martinez-Gonzalez, A. I.; Díaz-Sánchez, Á. G.; De La Rosa, L. A.; Bustos-Jaimes, I.; Alvarez-Parrilla, E. Alvarez-Parrilla, E.: Inhibition Of A-Amylase By Flavonoids: Structure Activity Relationship (Sar). Spectrochim. Acta, Part A 2019, 206, 437-447.

(17) Ren, C.; Xiong, W.; Li, J.; Li, B. Comparison Of Binding Interactions Of Cyanidin-3-O-Glucoside To B-Conglycinin And Glycinin Using Multi-Spectroscopic And Thermodynamic Methods. Food Hydrocolloids 2019, 92, 155-162.

(18) Fairbanks, S. D.; Robertson, C. C.; Keene, F. R.; Thomas, J. A.; Williamson, M. P. Structural Investigation Into The Threading Intercalation Of A Chiral Dinuclear Ruthenium (Ii) Polypyridyl Complex Through A B-Dna Oligonucleotide. J. Am. Chem. Soc. 2019, 141, 4644-4652.

(19) Zhang, Y.-P.; Li, Y.; Xu, G.-C.; Li, J.-Y.; Luo, H.-Y.; Li, J.-Y.; Zhang, L.; Jia, D.-Z. Synthesis, Crystal Structure, Dna/Bovine Serum Albumin Binding And Antitumor Activity Of Two Transition Metal Complexes With 4-Acylpyrazolone Derivative. Appl. Organomet. Chem. 2019, 33, No. E4668.

(20) Morgan, S. M.; El-Sonbati, A. Z.; Eissa, H. R. Geometrical Structures, Thermal Properties And Spectroscopic Studies Of Schiff Base Complexes: Correlation Between Ionic Radius Of Metal Complexes And Dna Binding. J. Mol. Liq. 2017, 240, 752-776.

(21) Layek, S.; Anuradha, B.; Agrahari, B.; Pathak, D. D. Synthesis And Characterization Of A New Pd (Ii)-Schiff Base Complex [Pd (Apd) 2]: An Efficient And Recyclable Catalyst For Heck-Mizoroki And Suzuki-Miyaura Reactions. J. Organomet. Chem. 2017, 846, 105112.
(22) Janssen-Müller, D.; Schlepphorst, C.; Glorius, F. Privileged Chiral N-Heterocyclic Carbene Ligands For Asymmetric TransitionMetal Catalysis. Chem. Soc. Rev. 2017, 46, 4845-4854.

(23) Popova, E. A.; Protas, A. V.; Trifonov, R. E. Tetrazole Derivatives As Promising Anticancer Agents. Anti Canc. Agents Med. Chem. 2017, 17, 1856-1868.

(24) Zhang, B.; Luo, H.; Xu, Q.; Lin, L.; Zhang, B. Antitumor Activity Of A Trans-Thiosemicarbazone Schiff Base Palladium (Ii) Complex On Human Gastric Adenocarcinoma Cells. Oncotarget 2017, 8, 13620.

(25) Gaspari, R.; Prota, A. E.; Bargsten, K.; Cavalli, A.; Steinmetz, M. O. Structural Basis Of Cis-And Trans-Combretastatin Binding To Tubulin. Chem 2017, 2, 102-113.

(26) Motswainyana, W. M.; Onani, M. O.; Madiehe, A. M. Bis (Ferrocenylimine) Palladium (Ii) And Platinum (Ii) Complexes: Synthesis, Molecular Structures And Evaluation As Antitumor Agents. Polyhedron 2012, 41, 44-51.

(27) Ehrmann, F. R.; Stojko, J.; Metz, A.; Debaene, F.; Barandun, L. J.; Heine, A.; Diederich, F.; Cianférani, S.; Reuter, K.; Klebe, G. Soaking Suggests "Alternative Facts": Only Co-Crystallization Discloses Major Ligand-Induced Interface Rearrangements Of A Homodimeric Trna-Binding Protein Indicating A Novel Mode-OfInhibition. PloS One 2017, 12, No. e0175723.

(28) Manjunath, M.; Kulkarni, A. D.; Bagihalli, G. B.; Malladi, S.; Patil, S. A. Bio-Important Antipyrine Derived Schiff Bases And Their Transition Metal Complexes: Synthesis, Spectroscopic Characterization, Antimicrobial, Anthelmintic And Dna Cleavage Investigation. J. Mol. Struct. 2017, 1127, 314-321.

(29) Tyagi, P.; Tyagi, M.; Agrawal, S.; Chandra, S.; Ojha, H.; Pathak, M. Synthesis, Characterization Of 1, 2, 4-Triazole Schiff Base Derived 3d-Metal Complexes: Induces Cytotoxicity In Hepg2, Mcf-7 Cell Line, Bsa Binding Fluorescence And Dft Study. Spectrochim. Acta, Part A 2017, 171, 246-257.

(30) Ekennia, A. C.; Osowole, A. A.; Olasunkanmi, L. O.; Onwudiwe, D. C.; Ebenso, E. E. Coordination Behaviours Of New (Bidentate N, O-Chelating) Schiff Bases Towards Copper (Ii) And Nickel (Ii) Metal Ions: Synthesis, Characterization, Antimicrobial, Antioxidant, And Dft Studies. Res. Chem. Intermed. 2017, 43, 37873811.

(31) Al-Fregi, A. A. Synthesis, Characterization And Molar Conductivity Study Of Some New Palladium (Ii) And Platinum (Ii) Complexes Containing Heterocyclic Tellurium-Dicarboxylato Ligands. Int. J. 2015, 3, 637-647.

(32) Bhal, S. K. Logp-Making Sense Of The Value. Adv. Chem. Dev. 2007, 1-4.

(33) Alpuche-Aviles, M. A.; Farina, F.; Ercolano, G.; Subedi, P.; Cavaliere, S.; Jones, D. J.; Rozière, J. Electrodeposition Of TwoDimensional Pt Nanostructures On Highly Oriented Pyrolytic Graphite (Hopg): The Effect Of Evolved Hydrogen And Chloride Ions. Nanomaterials 2018, 8, 668 .

(34) Janssen-Müller, D.; Schlepphorst, C.; Glorius, F. Correction: Privileged Chiral N-Heterocyclic Carbene Ligands For Asymmetric Transition-Metal Catalysis. Chem. Soc. Rev. 2017, 46, 5463.

(35) Zhang, P.; Sadler, P. J. Redox-Active Metal Complexes For Anticancer Therapy. Eur. J. Inorg. Chem. 2017, 2017, 1541-1548.

(36) Murray, S. G.; Hartley, F. R. Coordination Chemistry Of Thioethers, Selenoethers, And Telluroethers In Transition-Metal Complexes. Chem. Rev. 1981, 81, 365-414.

(37) Olsztynska, S.; Komorowska, M. Biomedical Engineering: Trends, Research and Technologies; Bod-Books on Demand, 2011.

(38) Kuntz, I., Jr; Gasparro, F.; Johnston, M., Jr; Taylor, R. Molecular Interactions And The Benesi-Hildebrand Equation. J. Am. Chem. Soc. 1968, 90, 4778-4781.

(39) Suntharalingam, K.; Mendoza, O.; Duarte, A. A.; Mann, D. J.; Vilar, R. A Platinum Complex That Binds Non-Covalently To Dna And Induces Cell Death Via A Different Mechanism Than Cisplatin. Metallomics 2013, 5, 514-523.

(40) Pyle, A. M.; Rehmann, J. P.; Meshoyrer, R.; Kumar, C. V.; Turro, N. J.; Barton, J. K. Mixed-Ligand Complexes Of Ruthenium 
(Ii): Factors Governing Binding To Dna. J. Am. Chem. Soc. 1989, 111, 3051-3058.

(41) Arshad, N.; Bhatti, M. H.; Farooqi, S. I.; Saleem, S.; Mirza, B. Synthesis, Photochemical And Electrochemical Studies On Triphenyltin (Iv) Derivative Of (Z)-4-(4-Cyanophenylamino)-4-Oxobut-2Enoic Acid For Its Binding With Dna: Biological Interpretation. Arabian J. Chem. 2016, 9, 451-462.

(42) Aslanoglu, M. Electrochemical And Spectroscopic Studies Of The Interaction Of Proflavine With Dna. Anal. Sci. 2006, 22, 439443.

(43) Ibrahim, M. S.; Shehatta, I. S.; Al-Nayeli, A. A. Voltammetric Studies Of The Interaction Of Lumazine With Cyclodextrins And Dna. J. Pharmaceut. Biomed. Anal. 2002, 28, 217-225.

(44) Lepecq, J.-B.; Paoletti, C. A Fluorescent Complex Between Ethidium Bromide And Nucleic Acids: Physical-Chemical Characterization. J. Mol. Biol. 1967, 27, 87-106.

(45) Zhang, Y.; Chen, X.; Gueydan, C.; Han, J. Plasma Membrane Changes During Programmed Cell Deaths. Cell Res. 2018, 28, 9-21.

(46) Meyer, M.; Essack, M.; Kanyanda, S.; Rees, J. G. A Low-Cost Flow Cytometric Assay For The Detection And Quantification Of Apoptosis Using An Anionic Halogenated Fluorescein Dye. Biotechniques 2008, 45, 317-320.

(47) Park, S.-Y.; Kim, I.-S. Engulfment Signals And The Phagocytic Machinery For Apoptotic Cell Clearance. Exp. Mol. Med. 2017, 49, No. E331.

(48) Meyer, M.; Essack, M.; Kanyanda, S.; Rees, J. G. A low-cost flow cytometric assay for the detection and quantification of apoptosis using an anionic halogenated fluorescein dye. BioTechniques 2008, 45, $317-320$.

(49) Sangster, J. Octanol-Water Partition Coefficients: Fundamentals And Physical Chemistry. Eur. J. Med. Chem. 1997, 32, 842.

(50) Minick, D. J.; Frenz, J. H.; Patrick, M. A.; Brent, D. A. A Comprehensive Method For Determining Hydrophobicity Constants By Reversed-Phase High-Performance Liquid Chromatography. J. Med. Chem. 1988, 31, 1923-1933.

(51) Liao, B.-L.; Yin, X.-J. Synthesis, Structure And High Photocatalytic Performance Of A Novel Vanadium (V) Complex Based On Pyridine-2, 4, 6-Tricarboxylic Acid. Inorg. Nano-Met. Chem. 2018, 48, 427-433.

(52) Sheldrick, G. M. Crystal Structure Refinement With Shelxl. Acta Crystallogr., Sect. C: Struct. Chem. 2015, 71, 3-8.

(53) Bourhis, L. J.; Dolomanov, O. V.; Gildea, R. J.; Howard, J. A. K.; Puschmann, H. The Anatomy Of A Comprehensive Constrained, Restrained Refinement Program For The Modern Computing Environment-Olex2 Dissected. Acta Crystallogr., Sect. A: Found. Adv. 2015, 71, 59-75.

(54) Wang, F.; Gao, L.; Zhao, Q.; Zhang, Y.; Dong, W.-K.; Ding, Y.J. A Highly Selective Fluorescent Chemosensor For Cn- Based On A Novel Bis (Salamo)-Type Tetraoxime Ligand. Spectrochim. Acta, Part A 2018, 190, 111-115. 